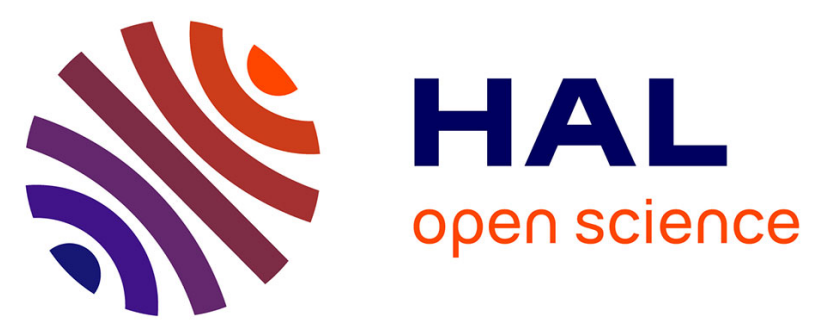

\title{
Early Crioceratites (heteromorphic ammonites) from the lower Hauterivian of south-eastern France: systematics, intraspecific variation and biostratigraphic implications
}

Didier Bert, Stéphane Reboulet, Benjamin Vernet, Stéphane Bersac, Léon Canut

\section{To cite this version:}

Didier Bert, Stéphane Reboulet, Benjamin Vernet, Stéphane Bersac, Léon Canut. Early Crioceratites (heteromorphic ammonites) from the lower Hauterivian of south-eastern France: systematics, intraspecific variation and biostratigraphic implications. Cretaceous Research, 2021, 126, pp.104903. 10.1016/j.cretres.2021.104903 . insu-03236518

\section{HAL Id: insu-03236518 \\ https://hal-insu.archives-ouvertes.fr/insu-03236518}

Submitted on 26 May 2021

HAL is a multi-disciplinary open access archive for the deposit and dissemination of scientific research documents, whether they are published or not. The documents may come from teaching and research institutions in France or abroad, or from public or private research centers.
L'archive ouverte pluridisciplinaire HAL, est destinée au dépôt et à la diffusion de documents scientifiques de niveau recherche, publiés ou non, émanant des établissements d'enseignement et de recherche français ou étrangers, des laboratoires publics ou privés. 


\section{Journal Pre-proof}

Early Crioceratites (heteromorphic ammonites) from the lower Hauterivian of southeastern France: systematics, intraspecific variation and biostratigraphic implications

Didier Bert, Stéphane Reboulet, Benjamin Vernet, Stéphane Bersac, Léon Canut

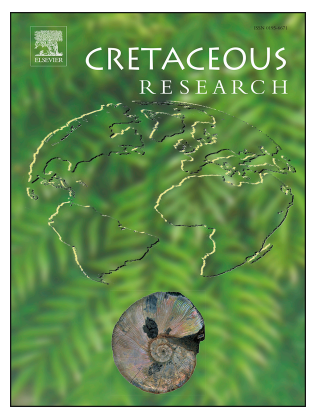

PII: S0195-6671(21)00150-6

DOI: https://doi.org/10.1016/j.cretres.2021.104903

Reference: YCRES 104903

To appear in: Cretaceous Research

Received Date: 27 January 2021

Revised Date: 15 May 2021

Accepted Date: 17 May 2021

Please cite this article as: Bert, D., Reboulet, S., Vernet, B., Bersac, S., Canut, L., Early Crioceratites (heteromorphic ammonites) from the lower Hauterivian of south-eastern France: systematics, intraspecific variation and biostratigraphic implications, Cretaceous Research, https://doi.org/10.1016/ j.cretres.2021.104903.

This is a PDF file of an article that has undergone enhancements after acceptance, such as the addition of a cover page and metadata, and formatting for readability, but it is not yet the definitive version of record. This version will undergo additional copyediting, typesetting and review before it is published in its final form, but we are providing this version to give early visibility of the article. Please note that, during the production process, errors may be discovered which could affect the content, and all legal disclaimers that apply to the journal pertain.

(c) 2021 Elsevier Ltd. All rights reserved. 
- D. BERT: let the work, wrote the article, made field-trip, made analyses;

- S. Reboulet: wrote the article, made field-trip;

- B. Vernet: wrote the article, made field-trip;

- S. Bersac: wrote the article, made analyses

- L. Canut: made field-trip

All the co-authors participated to the study, and have approved the final version of the manuscript. 
1 Early Crioceratites (heteromorphic ammonites) from the lower Hauterivian of south-eastern France: systematics, intraspecific variation and

\section{biostratigraphic implications}

*Corresponding author: didier.paleo@gmail.com

a: Réserve naturelle nationale géologique de Haute-Provence, Conseil départemental des Alpes de Haute-Provence, 13 rue du Docteur Romieu, CS 70216, F-04995 Digne-Les-Bains Cedex 9, France.

`: Laboratoire Géosciences, UMR-CNRS 6118, Université de Rennes-1, campus Beaulieu, bâtiment 15, F-35042 Rennes cedex, France.

c: Laboratoire du Groupe de recherche en Paléobiologie et biostratigraphie des Ammonites (GPA), 65 Grand rue, F-04170 La Mure-Argens, France.

d: Université de Lyon, UCBL, ENSL, CNRS, LGL TPE, Bâtiment Géode, 2 rue Dubois, 69622 Villeurbanne, France.

\section{Highlights}

- First Hauterivian acme of the Crioceratites belongs to C. claveli sp. nov. only

- C. claveli variation is under dimorphism, multipolar variation of order two and heterochronies

- Multipolar variation is not under the strict Buckman's 1st Law in C. claveli

- New C. claveli (Sub-)Zones are introduced in replacement of C. loryi (Sub-)Zones

- Crioceratites jurensis is revised; its synonymy with Davouxiceras nolani is rejected

\section{Abstract}


Two acmes of the genus Crioceratites were recorded in the current Crioceratites loryi Zone (lower Hauterivian) in the Lower Cretaceous series of south-eastern France (Vocontian Basin), both in the classic section of the Cheiron ravine (Castellane area) and in the Hauterivian GSSP area at La Charce. The revision of an abundant material allows us to define Crioceratites claveli sp. nov. The first acme and the first part of the second acme correspond to the range of $C$. claveli sp. nov. and not to $C$. loryi as previously admitted. The remaining of the second acme is related to this latter species solely. The great abundance of $C$. claveli sp. nov. in the lower interval Horizon allowed a detailed analysis of its variation around 3 factors: (1) dimorphism; (2) multipolar variation of order two here characterized by an absence of correlation between the ornamental and morphological shell parameters (non-covariant factors); and (3) ontogenic heterochronies, which depend on the robustness of the ornamentation only. On the other hand, the northern edge of the Provençal platform delivered C. jurensis (revised here) from the top part of the Acanthodiscus radiatus Zone, which reduces the gap with the older Crioceratites known in the uppermost Valanginian. Finally, the study of the stratigraphic distribution of $C$. claveli sp. nov. and C. loryi leads to propose the new C. claveli (Sub)Zone instead of the C. loryi (Sub)Zone. This proposal for the southeastern France may have extension potential for the Mediterranean Province of the Mediterranean Caucasian Subrealm (Tethyan Realm).

Keywords: Heteromorphic ammonites; Crioceratites; Hauterivian; Intraspecific variability; Biozonation; France.

\section{Introduction}


The heteromorphic ammonite group related to Davouxiceras nolani (Kilian, 1910) s.l. was excluded from the Crioceratites Léveillé, 1837 s. str. and is now considered an Emericiceratidae Vermeulen, 2004 (see Klein et al., 2007, p. 67). Consequently, the appearance of the genus Crioceratites was recognized to coincide with that of Crioceratites loryi Sarkar, 1955 (index species of the current Crioceratites loryi Zone, Reboulet et al., 2018), that is to say widely beyond the base of the Hauterivian stage. This situation changed with the discovery of 'primitive Crioceratites' at the top part of the Valanginian by Reboulet (1996). However, the link between the Hauterivian and Valanginian Crioceratites was not then evident due to the hiatus that remained throughout the thick Acanthodiscus radiatus Zone (Reboulet, 1996, p. 277).

Research carried out in the south-east of France has shown that the stratigraphic distribution of the Crioceratites in the current $C$. loryi Zone is organized around two acmes (Bulot, 1995, tab. 16; Reboulet, 1996, fig. 23; and this work). However, when the stratigraphy is known with sufficient precision, only the elements of the second occurrence have been cited and figured in the literature (i.e. Thieuloy, 1972; Ropolo, 1995; Bulot, 1995, p. 93-94; Reboulet, 1996, p. 178, pl. 24, fig. 6): all these specimens correspond to the original representation of $C$. loryi from Sarkar (1955) and to the very accurate description of this species by Thieuloy (1972). It was therefore important to verify if the Crioceratites of the first acme indeed correspond to the same species, and if it does not, to verify their relations with $C$. loryi and to draw all the possible important biostratigraphic implications, $C$. loryi being a zonal index.

This research was carried out in the classic section of the Cheiron ravine (south-eastern France, Alpes de Haute-Provence department, south of the Vocontian Basin), which, although cited for a long time in the literature, has been the subject of only few studies and no precise survey (Cotillon, 1971, fig. 3). The detailed bed-by-bed survey of the Hauterivian in the Cheiron ravine was carried out for the first time by Vernet and Bert (Vernet, 2017, 
unpublished Master thesis) as part of an internship at the Réserve naturelle nationale géologique de Haute-Provence (RNNGHP). For the present work, this section was resampled and yielded numerous ammonites including many Crioceratites. In the lower part of the current $C$. loryi Zone (the first acme evoked previously; = new Crioceratites claveli Zone, this work) all the Crioceratites belong to the same species (here $C$. claveli sp. nov.). The study material of Reboulet (1996) from La Charce (the Hauterivian GSSP) was also reviewed, as well as new elements from the complementary Pommerol section (Reboulet, 2015; AguirreUrreta et al., 2019 - Drôme department, central part of the Vocontian Basin). The abundant material from the first acme made it possible to perform a statistical analysis and identify the variation of the sample studied on the basis of the intraspecific laws of variability recently explored by Bert (2014a,b; 2019).

Additional research in the neritic domain of the Arc de Castellane (Provençal platform boarder, southeastern France) did not allow finding the two occurrences of Crioceratites of the current $C$. loryi Zone. However, several specimens of a related species [Crioceratites jurensis (Nolan, 1894) - rehabilitated in this work] have been collected in the upper part of the $A$. radiatus Zone, making it currently the oldest recognized Crioceratites s. str. species in the Hauterivian.

\section{Geological setting}

The three main sections studied belong to the Vocontian Basin series (Paquier, 1900 - Fig. 1). During the Early Cretaceous, the Vocontian Basin was located at a palaeolatitude of $\sim 30^{\circ} \mathrm{N}$ in a marginal marine position of the western Ligurian Tethys Ocean. This west-east oriented basin corresponded to a deep (a few hundred meters) depositional environment (pelagic series), and included the Diois-Baronnies region and the tectonic arc of Digne-Castellane in 
the west and east parts, respectively (Ferry, 2017). It was surrounded by slopes (transitional domain, hemiplegic series) and platforms (neritic series; Vercors, Vivarais and Provence regions). The dilated/expanded Hauterivian sections of the Vocontian Basin s.l. provide good conditions to follow the succession and evolution of ammonite faunas with great precision.

The Cheiron ravine (CHE - Castellane; Cotillon, 1971) provided the main part of the fossils studied. Although located in the pelagic domain of the southern part of the Vocontian Basin (the Eastern Subalpine Basin in the sense of Ferry, 2017), this section is very close to the hemipelagic domain from which it receives some influences (Fig. 1). From a structural point of view, this section belongs to the southern subalpine chains of the Arc de Castellane, which are the outermost units of the Alpine Arc. The La Charce (LCH - Hauterivian GSSP; Reboulet et al., 1992; Reboulet, 1996; Reboulet and Atrops, 1999; Mutterlose et al., 2020) and Pommerol sections (POM - Drôme department; Reboulet, 2015; Aguirre-Urreta et al., 2019) are located in the western part of the Vocontian Basin (the Vocontian through in the sense of Ferry, 2017), in the pelagic domain (Fig. 1).

The successions of the three sections studied (CHE, LCH, POM) are characterized by marlstone-limestone alternations, which have been interpreted as the result of cycles in the production of calcareous nannoplankton caused by climatic fluctuations in the Milankovitch frequency band (Cotillon et al., 1980; Giraud et al., 1995). Alternatively, Reboulet et al. (2003) have proposed a model of cyclic export of carbonate mud from shallow platform environments towards the basin for the Valanginian successions of the Vocontian Basin. Occasionally, synsedimentary slumps occurred in the basin.

Some sections of the Provençal platform boarder (Arc de Castellane) were sampled for the present work (Rougon and La Palud-sur-Verdon area in the Alpes de haute-Provence department: CAR, PV2 - Cotillon, 1971; Bulot et al., 1995; Reboulet, 1996 - and Bargème 
area in the Var department: COU1; Fig. 1). These sections are characterized by neritic deposits with often reduced and sometimes discontinuous sedimentation, in particular in the lower Hauterivian.

\section{Material and methods}

Stratigraphy. The Crioceratitidae are relatively rare in the upper Valanginian and more abundant in the lower Hauterivian substage (Reboulet, 1996, figs. 22-23). For this stratigraphic interval, numerous works dealing with paleontology and biostratigraphy were made during the last four decades; they allowed to improve the zonal scheme of the upper Valanginian-lower Hauterivian of the south-east France basin (Thieuloy, 1977; Reboulet et al., 1992; Bulot et al., 1993, 1995; Thieuloy and Bulot, 1993; Bulot, 1995; Bulot and Thieuloy, 1995; Reboulet, 1996, 2015; Reboulet and Atrops, 1999). These studies provide a sound base for the standard Mediterranean ammonite scale accepted by the Kilian Group (Hoedemaeker et al., 2003; Reboulet et al., 2006; 2009; 2011; 2014; 2018); this Lower Cretaceous standard zonation is applied here.

The terminologies used in this paper (biostratigraphy and chronostratigraphy versus geochronology) respect the standards of the International Commission on Stratigraphy (Salvador, 1994).

Material. This study focuses on the discovery of new bed-by-bed sampled material of the genus Crioceratites in the lower Hauterivian. The main part of this material (122 specimens) comes from the sections CHE (88 specimens), LCH (26 specimens) and POM (8 specimens) and belongs to the species $C$. claveli sp. nov. Five other specimens of the little-known species C. jurensis were collected in the sections CAR, PV2 and COU1. 
All the sections studied in the Alpes de Haute-Provence and Var departments belong to the protected perimeter of the 'Réserve naturelle nationale géologique de Haute-Provence' (RNNGHP), managed by the Departmental Council of the Alpes de Haute-Provence on behalf of the French State. The section LCH is the GSSP of the Hauterivian stage; this site is protected as an 'Espace naturel sensible' (Mutterlose et al., 2020).

Repositories. The material from $\mathrm{LCH}$ and POM sections is stored in the palaeontological collections of the Claude Bernard University of Lyon (France, collections of Reboulet, and Reboulet and Noclin). The material collected in the CHE section (Bert's collection) is curated by the RNNGHP. Some interesting specimens were added to the study albeit they are in a private collection (L. Canut): they are a minority, and of course they are never used as type specimens; the curatoring of these specimens is monitored by the RNNGHP.

Collections acronyms: MHNG=Museum of Natural history of Geneva (Switzerland); FSL=Faculté des Sciences de Lyon; RNNGHP=Réserve naturelle nationale géologique de Haute-Provence; DBT=D. Bert; LCT=L. Canut.

Measurements. The ammonoid fauna is relatively well preserved, but the fragmentation of specimens can be frequent in some beds. Dissolution of the ammonoid shells is the norm and specimens are preserved as internal calcareous moulds. The compaction of ammonites sampled in the pelagic part of the Vocontian Basin is relatively important, particularly for the phragmocone part of the shell. Consequently, some characteristics such as the thickness of whorl section cannot be observed and compared most of the time. The suture lines are not always well preserved (especially in pelagic deposits), however there systematic presence indicates the beginning of the body chamber. The abbreviations used for the measurements (mm) are: $\mathrm{D}=$ diameter; $\mathrm{H}=$ whorl height; $\mathrm{W}=$ whorl thickness; $\mathrm{U}=$ umbilical diameter; $\mathrm{h}=$ spiral hiatus; $\mathrm{Nt} / 2=$ number of tuberculate (main) ribs per half whorl; $\mathrm{Ni} / 2=$ number of smooth ribs (intercalatories) per half whorl. When measurements were taken at multiple diameters on the 
same specimen, the angle alpha between each successive measurement has been shown in the tables.

Analysis. In the present work, the sample of Crioceratites claveli sp. nov. from the basis of its stratigraphic range (the first acme previously evoked, here the $C$. claveli lower interval Horizon) is the only sufficiently large and homogeneously preserved to be statistically analyzed; this would also allows avoiding time-averaging as much as possible. Statistical analyses and tests were carried out using PAST, version 3 (Hammer et al., 2001). The method used has already been described by Bersac and Bert (2012) and Bert (2014a), and will not be given in detail here again. A digital matrix was made from different measures of the quantifiable characters (continuous and discrete variables) and ratios of some of them. Continuous parameters tested were $\mathrm{D}, \mathrm{H}, \mathrm{U}$ and $\mathrm{h}$. The specimens often have a side embedded in the rock and most are compressed post mortem, so the variables associated with W were not tested due to lack of effective (significance level not reached). This is also the case for the diameters of the ontogenic stages, which could not be integrated into the statistical analysis for the same reasons, but they were taken into account in the descriptive analysis. Conventional ratio H/D (relative height), U/D (relative umbilicus) and U/H were calculated. The discrete variables tested are $\mathrm{Nt} / 2$ and $\mathrm{Ni} / 2$. Significance level of probability tests was set at $p=0.05$. Univariate and bivariate analyses were employed to visualize and test the homogeneity of the sample, the possible variation through ontogeny, and correlations between parameters two by two. Multivariate analysis allows (1) investigation of the contribution of each variable relative to the total morphospace occupation of the sample, (2) investigation of the relationships between variables, and (3) to test groups recognized in the descriptive analysis (i.e. dimorphs) considering all the variables simultaneously.

\section{Description of the sections}




\subsection{The Cheiron ravine}

The palaeontological site of the Cheiron ravine has been known very probably since the beginning of the 19th century and has been visited for a very long time by local paleontologists (Astier, Jaubert, Duval-Jouve, Emeric, Audoul, Puzos, etc.). This long frequentation allowed the introduction of at least 30 species of ammonites from the Lower Cretaceous series, including zonal indexes [for example Plesiospitidiscus ligatus (d'Orbigny, 1841)], which make this site one of the most important for the Hauterivian stage in the southeast of France. Despite this historical past, the only study of this locality was from Cotillon (1971) who gave an imprecise synthetic geological section.

The Hauterivian lithology of the Cheiron ravine is composed of a relatively regular alternation of marlstone and limestone beds over $205 \mathrm{~m}$ thick, more compact at the top of the series. Only a limited slump area disturbs the Hauterivian succession in the lower part of the Subsaynella sayni Zone and causes an about $5 \mathrm{~m}$ thick invisibility. The beds and interbeds are thick in the Acanthodiscus radiatus Zone, and then they tend to thin out in the current Crioceratites loryi Zone (Fig. $2 ;=$ new $C$. claveli Zone, this work). The top part of the current $C$. loryi Subzone (= new $C$. claveli Subzone, this work) is formed by a small marly ledge between the beds 194-198. A second marly ledge is located at the limit between the Olcostephanus jeannoti Subzone and the Lyticoceras nodosoplicatum Zone (beds 206-214). In the current C. loryi Zone (= new $C$. claveli Zone, this work), three beds are exceptionally rich in fossils: bed 179 at the base of the zone (first acme of the genus Crioceratites), the very marly bed $195(10 \mathrm{~cm}$ thick), which constitutes a Konzentrat-Lagerstätte type deposit (bioclatic accumulation), and bed 197 just below the O. jeannoti Subzone. Beds 195-197 form the second acme of the 
genus. In bed 195, the fossils are very compressed and fragile structures such as spines are often kept in place; we also note the presence of many aptychi and very scattered grains of glaucony. The fauna is mainly made up of $C$. claveli sp. nov. in beds 179 and 195, which contain the First Occurrence (FO) and Last Occurrence (LO) of the species respectively, and by $C$. loryi in beds $196-197$. In the other beds of the current $C$. loryi Subzone (= new $C$. claveli Subzone, this work), Neolissoceras grasianum (d'Orbigny, 1841) is often the more abundant. The first Crioceratites curnieri Ropolo, 1992 have been observed to date in bed 201.

\subsection{The La Charce-Pommerol sections}

A detailed lithology of the upper Valanginian-lower Hauterivian at La Charce was made previously by Reboulet et al. (1992), Bulot et al. (1993; 1995), Bulot (1995), Reboulet (1996; 2015) and Reboulet and Atrops (1999). In the upper Valanginian, the Saynoceras verrucosum Zone is a marly-dominated interval; the relative abundance of carbonate in the marlstonelimestone succession increases gradually during the Neocomites peregrinus and Criosarasinella furcillata zones. Carbonate-rich marlstone-limestone alternations predominates the lower Hauterivian beds (Acanthodiscus radiatus, Crioceratites loryi and Lyticoceras nodosoplicatum zones).

In the La Charce section, the continuity of the marlstones-limestone alternation deposits is interrupted by two slumps in the lower Hauterivian observed at the top part of the A. radiatus Zone and across the boundary between the current $C$. loryi and L. nodosoplicatum zones. However, the stratigraphic intervals equivalent to these two slumps were correlated to the nearby Pommerol section characterized by undisturbed marlstone-limestone alternations (Reboulet, 2015; Aguirre-Urreta et al., 2019). These authors provided additional data allowing 
249

250

251

252

253

254

255

256

257

258

259

260

261

262

263

264

265

266

267

268

269

270

271

272

273

to complete more precisely the lower Hauterivian ammonoid distribution previously established for the La Charce section.

\section{Descriptive palaeontology}

Class: Cephalopoda Cuvier, 1798

Order: Ammonoidea Agassiz, 1846

Suborder: Ammonitina Hyatt, 1889

Superfamily: Perisphinctoidea Steinmann, 1890

Family: Crioceratitidae Gill, 1871

Genus Crioceratites Léveillé, 1837

Type species. Crioceratites duvalii Léveillé, 1837.

\section{Crioceratites jurensis (Nolan, 1894)}

\section{Figs. 3-5}

\section{Synonymy.}

vm 1861 Ancyloceras duvalii, 'type 1'; Pictet and Campiche: p. 37-39, p. 49; pl. 47bis, fig. 1ab.

1894 Crioceras picteti var. jurensis nov.; Nolan: p. 192.

1910 Crioceras jurense; Kilian: p. 270.

?1936 Crioceratites sp. juv. gr. jurensis; Breistroffer: p. 145.

non 1967 Crioceratites jurensis; Dimitrova: p. 44; pl. XVIII, fig. 1.

Holotype by monotypy. Specimen MHNG GEPI 16787 (Fig. 3) of the Pictet's collection, curated in the Museum of Natural history of Geneva (Switzerland). 
Type locality. The Ravin Saint-Martin area, near Escragnolles (Alpes-Maritimes, southeastern France).

Type horizon. Unspecified in the original work of Pictet and Campiche (1861), but the type specimen is said by these authors (p. 39) to come from a bed that yielded also Acanthodiscus radiatus (Bruguière, 1789), Oosterella cultrata (d'Orbigny, 1841), Neolissoceras grasianum (d'Orbigny, 1841) and Lyticoceras cryptoceras (d'Orbigny, 1840). In the type locality, the Hauterivian basis is condensed in a fossiliferous level with numerous Acanthodiscus Uhlig, 1905 and Leopoldia Mayer-Eymar, 1887 (Kilian and Zürcher, 1896), and it is highly probable that this level has also delivered the type specimen of Crioceratites jurensis.

Geographic distribution. Southeastern France (neritic domain of the 'Arc de Castellane'), Switzerland ('Hauterive marlstones' in Pictet and Campiche, 1861, p. 49).

Stratigraphic distribution. New specimens were collected (LC and DB) at La Palud-surVerdon and Carajuan (Rougon, south-east of France) together with numerous Leopoldia above the beds rich in Acanthodiscus radiatus (Carajuan, bed 88 in Bulot et al., 1995, fig. 7), just below the gap of most of the current $C$. loryi Zone (= new $C$. claveli Zone, this work). This species is therefore restricted to the upper part of the A. radiatus Zone, without further details in the current state of knowledge (= Leopoldia buxtorfi Horizon of Bulot, 1995).

Material studied (N=6). Six specimens, all from the platform boarder of the "Arc de Castellane' (South-East of France), including the cast of the holotype provided by Lionel Cavin (curator of the Museum of Natural history of Geneva). Two specimens (DBT.BC47 and DBT.BC48) are from the bed 88 of the Carajuan section (Rougon, Alpes de Haute-Provence department - see Bulot et al., 1995, fig. 7). Two specimens are from the same equivalent level in an unpublished section near La Palud-sur-Verdon (Alpes de Haute-Provence, DBT.BG31 and LCT.7Z). The last specimen is from the locality of Bargème (unpublished section - Var 
department, DBT.BC49), in a condensed bed assigned to the A. radiatus Zone with ferruginous ooliths.

Description. The shell is crioconic, rather weakly uncoiled, with a spiral hiatus which increases regularly with growth. The whorl section is relatively depressed, nearly sub-circular, more compressed in the inner whorls, but this is increased by the greater post mortem compression at this level. Taking into account the length of the adult body chamber (more than $1 / 3$ of a whorl), the reconstructed size reached $120 \mathrm{~mm}$ (DBT.BC47 - Fig. 4) to $165 \mathrm{~mm}$ in diameter (LCT.7Z - Fig. 5; DBT.BG31). The ontogenetic sequence is as follows (note that the ornamentation of the ventral area is known on the studied specimens only from the ontogenetic stage 4):

- Stage 1 'initial trituberculate' up to about $15-20 \mathrm{~mm}$ in diameter: the ornamentation is differentiated with main trituberculate ribs bearing large nodular tubercles; the lateral tubercle is located towards the mid-flank. The intercalary ribs are smooth and few in number.

- Stage 2 'with nodular periventral tubercles' up to $\mathrm{D}=50-55 \mathrm{~mm}$ : the ornamentation is weakly differentiated, with main bituberculate ribs bearing tubercles near the umbilicus and on the periventral area. The latter tubercle is distinctly nodular. Fasciculations (several sickleribs that start from the same periumbilical tubercle) are exceptional and limited to a very few ribs only. The periventral tubercle is thorny compared to the periumbilical one; it is well marked and lengthened in the longitudinal direction. The ribs are slightly tipped forward in the middle of the flanks, which gives them a flexuous appearance.

- Stage 3 'with spiny periventral tubercles', up to $\mathrm{D}=110-130 \mathrm{~mm}$ : the ribs are better differentiated with the total loss of the fasciculation and the acquisition of true trituberculate main ribs generally separated by 5-6 smooth interribs. The tubercles, however, remain inconspicuous on the material studied; the periventral tubercle loses its nodular appearance characteristic of the previous stage. 

than in the previous stage; the intercalary ribs are reinforced, spaced out, and their distinction from the main ribs becomes sometimes less obvious. The main ribs (and sometimes the

326 intercalaries when they are strong) remain trituberculate with a lateral tubercle. They can be grouped into doublets separated by a weak constriction with a flat bottom. The bifurcations on the top of the flanks are rare. All the ribs cross the ventral area, and the main ones subtentially strengthen. The body chamber (probably adult) starts between 90 and $110 \mathrm{~mm}$ in diameter.

The suture lines are very indented, of the ELUI type according to the terminology used by Wiedmann (1966), with a well marked and deep lateral lobe L. It is trifid and each of the three branches is narrow and well developed. The umbilical lobe $\mathrm{U}$ is also trifid, shallower than $\mathrm{L}$ and more stocky. The siphonal lobe $\mathrm{E}$ is shallower than L; it is bifid with elongated and narrow terminal branches. The following formula is respected: $\mathrm{L}>\mathrm{E}>\mathrm{U}$.

Discussion. Dimorphism is not yet known in C. jurensis, probably due to a lack of specimens. By comparison with the other related species for which the dimorphic pairs have been recognised (C. loryi and $C$. claveli sp. nov.), it seems that the specimens described herein all belong to the macroconch dimorph.

The specimen from the Pictet's collection, shown by Pictet and Campiche (1861, pl. 47 bis, fig. 1), and which was later used as type for $C$. jurensis by Nolan (1894) was never refigured. It could be found by Lionel Cavin in the collections of the Museum of Geneva and the synonymy with Davouxiceras nolani proposed by Sarkar (1955), and followed by Klein et al. (2007), is rejected here. Actually, Pictet and Campiche (1861, p. 38-39, 49) themselves recognized the differences between this specimen (their fig. 1) and the one in their figure 2 (Pictet and Campiche, 1861, pl. 47bis), which the latter would later become the type of $D$. nolani. The two species are clearly not of the same group, $C$. jurensis belonging to the genus

\section{Crioceratites s.str.}


349

350

351

352

353

354

355

356

357

Thus, Crioceratites jurensis is also very different from Davouxiceras coniferus (Busnardo et al., 2003), although they can be found in the same levels. This latter species has a much more open coiling. New specimens (LC, DB and Poupon collections) show that it could reach a large to very large adult size, between $360 \mathrm{~mm}$ and up to probably around $500 \mathrm{~mm}$. We do not recognize in D. coniferus the ontogenic stages described in $C$. jurensis: in the former, the trituberculation is constant with ribs always differentiated into very strong mains ribs and smooth intercalaries, which seem to become scarce or even disappear on the adult body chamber. This is the morphology usually accepted by authors as characteristic of the group of 'Davouxiceras nolani' sensu lato (Klein et al., 2007). The type specimen of D. coniferus and the specimen studied by Reboulet (1996; = Crioceratites n. sp. 1, pl. 24, fig. 7), reported to this species by Busnardo et al. (2003), are assigned to the lowermost part of the Hauterivian (A. radiatus Zone). Since then, Vašíček (2005) has reported D. coniferus in the upper Valanginian (Criosarasinella furcillata Zone and Subzone).

C. jurensis is closer to C. loryi (Fig. 6), with which it shares the general morphology of the shell, and with which it has many affinities. The adult size of $C$. jurensis appears to be slightly smaller than that of $C$. loryi $(150-165 \mathrm{~mm}$ vs. $180 \mathrm{~mm})$. The initial trituberculate stage is common to the both species, but it is distinctly shorter in C. loryi $(5-7 \mathrm{~mm}$ vs. $15-20 \mathrm{~mm})$. Stage 2 is slightly longer in $C$. jurensis $(50-55 \mathrm{~mm}$ vs. $40 \mathrm{~mm})$, but the characteristic fasciculations of $C$. loryi are almost absent or only limited to a few ribs. $C$. jurensis stage 3 is also longer (110-130 mm vs. $90 \mathrm{~mm})$, with the presence of systematic trituberculate main ribs, which is not the case in $C$. loryi where the ribs are bituberculate. Finally, the adult stages 4 of the both species are quite similar, but the ribs are still trituberculate in $C$. jurensis. Note that this aspect is less evident in the type of $C$. jurensis due to wear of the specimen. 
C. jurensis has a more regular coiling than C. curnieri, which varies between crioconic to

375

376 subaspinoceratic poles. In stages 3 and 4, C. jurensis shows fairly constant trituberculate ribs pattern that is never the case with $C$. curnieri, which is bi- or even monotuberculate. The ornamentation of $C$. jurensis is markedly less regular than that of $C$. curnieri. Finally, $C$. curnieri is more recent, as it appears in the O.jeannoti Subzone and becomes more abundant in the L. nodosoplicatum Zone (Ropolo, 1992; Bulot, 1995; Reboulet, 2015; Aguirre-Urreta et al., 2019).

Some specimens of Crioceratites heterocostatus Mandov, 1976 could have an aspinoceratic coiling of the adult body chamber (see Reboulet, 1996, pl. 24, fig. 1), which is never the case in $C$. jurensis. $C$. heterocostatus is also smaller with a diameter up to $100 \mathrm{~mm}$ (vs. at least 150-165 mm). We recognize almost the same succession of ontogenic stages (in particular stages 1 and 2, which are quite similar), with the exception of stage 3 'with spiny periventral tubercles', absent in C. heterocostatus, which de facto prolongs stage 2 up to $60-70 \mathrm{~mm}$ in diameter (vs. 50-55 $\mathrm{mm}$ in $C$. jurensis). There are still other differences between these two species: the strongly trituberculate juvenile stage 1 is shorter in $C$. jurensis (15-20 mm vs. 20$30 \mathrm{~mm}$ ); in adult stage $4, C$. heterocostatus is bituberculate while $C$. jurensis is trituberculate; rib bifurcations on the upper flanks are rarer in C. jurensis (stage 4). On the other hand, the duplication of ribs on the adult body chamber is present in the both species, as in C. loryi. Following Vašíček (2005, p. 252, see also Klein et al., 2007, p. 44, note 31) and Company (in Klein et al., 2007, p. 40, note 30), we consider that Crioceratites primitivus Reboulet, 1996 is a junior synonym of $C$. heterocostatus Mandov 1976. This latter is reported from the Menhegini-Cryptoceras Zone of the Western Balkanids, which places it in the lower Hauterivian for Mandov (1976), while it would be more likely uppermost Valanginian for 
400

401

402

403

404

405

406

407

408

409

410

411

412

413

414

415

416

417

418

419

420

421

Thieuloy (1977, p. 127). This older age, confirmed by Vašíček (1995, p. 171), reinforces the hypothesis of synonymy between the two species, with $C$. heterocostatus taking precedence.

Crioceratites claveli sp. nov.

Figs. 7-12

\section{Synonymy.}

1997 Crioceratites sp.; Faraoni et al.: p. 69, pl. 7, fig. 17.

Derivation of name. This species is dedicated to the memory of our French paleontologist colleague Bernard Clavel (1938-2018†).

Zoobank Record. LSID urn:lsid:zoobank.org:act:790B5346-0463-44D4-961BB111EA4D17AA.

Holotype. Specimen DBT.BB48 (Fig. 7a-b) of the Bert's collection, curated by the RNNGHP.

Type locality. The Cheiron ravine, near Castellane, section CHE (Alpes de Haute-Provence, southeastern France).

Type horizon. The bed CHE/179 of the type locality, at the very basis of the Crioceratites loryi Zone in its current acceptation (= new C. claveli Zone, this work).

Geographic distribution. The species is currently known in south-east of France (Alpes de Haute-Provence and Drôme departments) and in Italy (Marche Apennines).

Stratigraphic distribution. The lower stratigraphic limit of C. claveli sp. nov. is the bed with the first acme of the genus Crioceratites at the lowermost part of the current $C$. loryi Zone (= new $C$. claveli Zone, this work) and its upper limit is in the second acme of the genus, just below the appearance of $C$. loryi at the top part of the current $C$. loryi Subzone (= new $C$. claveli Zone, this work and see also Reboulet, 1996, fig. 23). In the Cheiron ravine, this 
422

423

424

425

426

427

428

429

430

431

432

distribution includes the beds CHE/179-195 and the beds LCH/219-229 in the La Charce section.

Diagnosis. Dimorphic crioconic shell with weak spiral hiatus in the inner whorls. Four stages during ontogeny: stage 1 'initial trituberculate' up to $\mathrm{D}=9 \mathrm{~mm}$; stage 2 with 'nodular periventral tubercles' up to approximately $\mathrm{D}=20-35 \mathrm{~mm}$ for the microconchs and $\mathrm{D}=45-50$ $\mathrm{mm}$ for the macroconchs (differentiated ribs; main ribs bituberculate, exceptionally trituberculate; sometimes fasciculation with $2-3$ ribs); stage 3 'with spiny periventral tubercles', up to $\mathrm{D}=56-70 \mathrm{~mm}$ in microconchs and $\mathrm{D}=95-115 \mathrm{~mm}$ in macroconchs, with less regular and flexuous ornamentation than in the previous stage (irregular appearance of trituberculation - lateral tubercle); stage 4 'adult', up to $\mathrm{D}=78-90 \mathrm{~mm}$ for the microconchs and $\mathrm{D}=135-145 \mathrm{~mm}$, even $165 \mathrm{~mm}$, for the macroconchs, with well individualized trituberculate main ribs and frequent duplicating of the main ribs. Stages 2-4 show long and highly developed spines on the periumbilical, lateral and periventral tubercles.

Material studied $(\mathbf{N}=\mathbf{1 2 4})$. Ninety specimens are from the Cheiron ravine (CHE) near Castellane (Alpes de Haute-Provence, France): 32 are from bed CHE/179, which are numbered DBT.BB48, DBT.BB49, DBT.BB51 to DBT.BB76 and DBT.BB92 to DBT.BB94 (DBT.BB55 bears two specimens), 3 are from bed CHE/180, which are numbered DBT.BB71, DBT.BB74 and DBT.BB95, 1 is from bed 194 (DBT.BG49), and 54 are from bed 195 (DBT.BB79, DBT.BG49 to DBT.BG64 and DBT.BG67 to DBT.BG88, some numbers having several specimens). In addition some unnumbered fragmentary specimens where collected in beds 189, 190, 193 and 195 (Fig. 2). Height specimens are from Pommerol (POM), all from bed POM/219. They are temporarily numbered POM 219-2, 3, 5, 7, 8, 12, 20 and 23. Twenty-six specimens are from La Charce (LCH). They are numbered FSL 487738 (LCH/226), FSL 487736 a-j (LCH/220), $\quad$ FSL 487733 a-1 (LCH/219), FSL 487739 (LCH/225), FSL 487738 (LCH/226) and FSL 487743 a-b (LCH/229). 
Description. The shell is heteromorphic, of the crioconic type. The spiral hiatus is weak in the inner whorls, but this parameter can be parasitized by the significant post mortem crushing of the specimens in the phragmocone, and it tends to grow significantly in the adult body chamber (Fig. 8). Dimorphism was recognized by the adult size and the diameter reached by the various ontogenic stages. There are 4 stages during ontogenesis:

- Stage 1 'initial trituberculate' up to $\mathrm{D}=9 \mathrm{~mm}$ on average, with differentiated ribs, the main ones having large lateral tubercles at mid-flanks (Fig. 7f). The ribs are simple, straight or slightly retroverted. The section of the whorl is more rounded than on the rest of the shell.

- Stage 2 'with nodular periventral tubercles' up to approximately $\mathrm{D}=20-35 \mathrm{~mm}$ for microconchs and $\mathrm{D}=45-50 \mathrm{~mm}$ for macroconchs: the ornamentation is quite irregular from one specimen to another. The ribs are differentiated; the main ribs are bituberculate, exceptionally trituberculate (lateral tubercle very discreet when present - FSL 487736f). There is some variation in the strength and density of the ornamental pattern, and the more slender specimens have markedly less marked rib differentiation with very inconspicuous tubercles. Most often, fasciculation (several ribs starting from the same periumbilical tubercle) concerns only a small number of ribs (2-3); it is usually rare but more frequent in slender specimens. The periumbilical tubercle is thorny, slightly elongated in the direction of the rib which supports it. The periventral tubercle is quite nodular and sometimes groups together several ribs by fibulation (two lateral ribs which meet at the top of the flank - Fig. 9b-c). When the preservation conditions allow it (as for example in the CHE/195 bed), it is possible to observe that all the tubercles (periumbilical, lateral when present and periventral) are extended by a triangular elongated spine, more or less thin, even for poorly developed tubercles (Fig $7 \mathrm{~b}$ and 10 shows example of the lateral and periventral spines respectively; note that the periumbilical and lateral spines are unfortunately most often broken during the mecanical preparation process). The ribs are generally quite flexible: projected forward near 
the umbilical wall, they straighten between the first third and half of the flank. They do not pass through the siphonal area or are much erased and broaden there because of the thickening-out associated with the nodular appearance of the adjacent periventral tubercle.

- Stage 3 'with spiny periventral tubercles', up to $\mathrm{D}=56-70 \mathrm{~mm}$ in microconchs and $\mathrm{D}=95-115 \mathrm{~mm}$ in macroconchs, is close to the previous stage with an even less regular and flexuous ornamentation. The ribs are hardly differentiated in slender specimens. The tubercles are thorny and lose the nodular appearance of the previous stage. This stage is mainly marked by the irregular appearance of the trituberculation (lateral tubercle) from $\mathrm{D}=40$ and $50 \mathrm{~mm}$ respectively in the robust and slender microconch specimens, and $\mathrm{D}=55 \mathrm{~mm}$ in the macroconchs. Note that the lateral tubercle is absent in very slender specimens. As in the previous stage, all tubercles are extended by long, well-developed spines.

- Stage 4 'adult', up to $\mathrm{D}=78-90 \mathrm{~mm}$ for microconchs and $\mathrm{D}=135-159 \mathrm{~mm}$ for macroconchs (reconstructed up to $\mathrm{D}=165 \mathrm{~mm}$ on specimen DBT.BB52, see below - Fig. 8). The ornamentation becomes again a little more flexible than in the previous stage, with very well individualized trituberculate main ribs, especially in macroconchs. They are much reinforced with strong tubercles in robust specimens, especially the macroconchs, and a little less in slender specimens and microconchs. All the ribs strengthen on the ventral area. Duplication of the main ribs is frequent. In some microconchs, the ribs may become stronger and become slightly spaced. The adult body chamber starts at $\mathrm{D}=55-65 \mathrm{~mm}$ in microconchs and $\mathrm{D}=94-100 \mathrm{~mm}$ in macroconchs. At this stage again the tubercles are extended by spines. Dimorphism. Among the 42 macroconchs identified, four appear almost complete and can be considered as adults (preservation of stage 4 with approximation of the reinforced main ribs and more marked adoral projection): (1) the specimen DBT.BB52 is the largest with $140 \mathrm{~mm}$ in diameter $(\mathrm{Dph}=100 \mathrm{~mm}-$ Fig. 8) and a body chamber preserved on 1/4 of a whorl (reconstructed at more than $1 / 3$, it would measure approximately $\mathrm{D}=165 \mathrm{~mm}$ in diameter); (2) 
497

498

499

500

501

502

503

504

505

506

507

508

509

510

511

512

513

514

515

DBT.BB48 (Fig. 7a-b) and (3) DBT.BG58 of which only the end of the body chamber is missing (respectively Dph=94 and $99.82 \mathrm{~mm}$ ). (4) Specimen DBT.BG49 (Fig. 11) is an almost complete adult body chamber of $159 \mathrm{~mm}$ in diameter. Specimen DBT.BB55a (Fig. 9a) is also a macroconch, but it is almost wholly septate with a $72 \mathrm{~mm}$ diameter phragmocone, suggesting that it is probably an immature specimen. The other macroconchs are more fragmentary, but the ontogenic stage reached according to the diameter (often the ornamental 'adult' stage present on the body chamber) makes it possible to identify them.

Forty-three sufficiently complete microconchs have been identified. The most complete are specimens POM 219.2 (D=86 mm - Fig. 12a-b) and BDT.BB49 (D=78 mm - Fig. 7c-d), with a complete (adult) body chamber more than $1 / 3$ of a whorl and a phragmocone around $55 \mathrm{~mm}$ in diameter, and DBT.BG50 (D=78.4 mm - Fig. 10a), which shows approximated septa. Five other specimens present their phragmocone and at least part of the body chamber (DBT.BB54, DBT.BB57 to DBT.BB61 and FSL 487736g - Figs. 7f-g, 9b-c). The last specimens are fragments of body chambers alone (DBT.BB74) or showing the transition with the phragmocone (DBT.BB75).

The last 38 specimens are either juveniles that have not reached a sufficient development to be able to be attributed to one or the other dimorph, or too incomplete specimens that do not show the diameter of transition between the ontogenic stages. In all cases, below $45 \mathrm{~mm}$ in diameter the both antidimorphs are identical. Visually, the dimorphs can only be separated on the basis of their adult size and the ontogenetic stages achieved according to the diameter, but neither by the dimensional parameters of the shell nor by the aspect of the ornamentation (at equivalent stage).

The suture line is very indented and follows the ELUI formula (terminology of Wiedmann, 1966), with $\mathrm{L}>\mathrm{E}>\mathrm{U}$. The lateral lobe $\mathrm{L}$ is trifid, well developed, relatively symmetrical and deep. The umbilical lobe $\mathrm{U}$ is also trifid, shallower than $\mathrm{L}$ and more stocky. The siphonal lobe 
522

523

524

525

526

527

528

529

530

531

532

533

534

535

$\mathrm{E}$ is barely visible due to the compaction of the specimens. The lateral and umbilical saddles are well incised by an accessory lobe.

Discussion. The specimen of Crioceratites sp. described by Faraoni et al. (1997, p. 69, pl. 7, fig. 17) from the Marche Apennines (Mt Catria, Maiolica Formation, central Italy) could belong to the species $C$. claveli sp. nov. (microconch) because of its morphology, the presence of main trituberculate ribs at least from $\mathrm{D}=35 \mathrm{~mm}$ (the very inner whorls are poorly preserved), the presence of nodular lateroventral tubercles, which encompass several ribs before the onset of trituberculation, and the presence of long well-defined spines. This specimen is from bed 407 of the Chiaserna section assigned to the A. radiatus Zone (nonbasal) by Faraoni et al. due to the presence of Tescheniceras flucticulus (Thieuloy, 1977) and Spitidiscus meneghinii (Rodighiero, 1919) respectively in beds 392 and 405 . The last terms of the geological section could actually be more recent, since at La Charce these species are reported up quite high in the $A$. radiatus Zone, and even up to the base of the current $C$. loryi Zone (= new C. claveli Zone, this work) for S. meneghinii (Reboulet, 1996, fig. 23). Under these conditions, it is highly probable that bed 407 of the Chiaserna section is to be assigned to the base of the current $C$. loryi Zone (= new C. claveli Zone, this work).

C. claveli sp. nov. is closely related to $C$. loryi. The double acme in the distribution of $C$. loryi (LCH/219-220 and LCH/230-235) recorded by Reboulet (1996) at La Charce and at the Cheiron ravine (CHE/179-180 and CHE/194-195 - this work) is a result which led to a more careful attention in order to verify whether these two acmes could correspond to two different species or if the total vertical distribution corresponds to the solely species C. loryi. The present work clearly goes in favor of the first hypothesis. The differences between $C$. claveli sp. nov. and C. loryi are mainly focused on the ontogenic stages and the systematic presence of highly developed spines in $C$. claveli sp. nov. (Figs. 7a-b, c, g, 10a-c). In C. loryi, the 
'initial trituberculate' stage 1 is shorter $(5-7 \mathrm{~mm})$, stage 2 is very characteristic with the systematic presence of numerous fasciculated dense and homogeneous ribs, almost all similar, starting from the periumbilical tubercle. This fasciculate pattern is much rarer in C. claveli $\mathrm{sp}$. nov. and always limited to a few ribs only. The stage 3 in $C$. loryi shows very discreete trituberculation only on the extremely rare hyper-robust specimens; the ornamentation is more regular with a periumbilical tubercle always more discreet than in $C$. claveli sp. nov. Finally, in stage 4 (adult) of most macroconchs (and much more discreetly in microconchs and hyperslender macroconchs) the main ribs are clearly trituberculate in $C$. claveli sp. nov., with a sometimes very developed lateral tubercle extended by a long spine (as for example in the specimen BB48 - Fig. 7a-b), while the ribs are most often bituberculate in $C$. loryi. In some rare macroconchs of this latter species, trituberculation can be developed irregularly and fleetingly at the end of stage 4 with an always inconspicuous and unsystematic lateral tubercle that never shows the presence of a spine. In terms of adult size, $C$. loryi appears to be larger (105 mm versus $90 \mathrm{~mm}$ for microconchs and $180 \mathrm{~mm}$ versus $165 \mathrm{~mm}$ for macroconchs, see Fig. 6a), although this maximum size is not expressed in all adult macroconchs of C. loryi.

C. curnieri has a more variable coiling between a crioconic to a subaspinoceratic pole. However, the coiling of $C$. claveli sp. nov. is narrower and more regular since $C$. curnieri shows an increase in the uncoiling of the adult body chamber at the start of a shaft and a short hook (elliptical coiling), even in the case of the crioconic morphology. In all cases, C. curnieri is bituberculate, or even monotuberculate, without ever being trituberculate as in C. claveli sp. nov. Tuberculation is always very inconspicuous, unlike $C$. claveli sp. nov. in which every tubercles is prolonged by a well-developed spine. The ornamentation of C. curnieri is more regular in the alternation between the main and intercalary ribs. The periventral tubercles appear later in ontogeny, after the periumbilical tubercles (Ropolo, 1992, p. 67), which is not 
572

573

574

575

the case in $C$. claveli sp. nov. where the innermost whorls are trituberculate (stage 1). Then, the lateral tubercle disappears, making concomitant both the two periventral and periumbilical tubercles (stage 2), before its subsequent reappearance at stage 3. Adult stage 4 is also different, despite the strengthening of the main and secondary ribs in C. curnieri, which are more and more similar and spaced (sometimes bifurcated on the top of the flanks as can also be observed in some specimens of $C$. claveli sp. nov.), and despite the presence of constrictions. The ribs, on the other hand, remain there clearly differentiated and more spaced in $C$. claveli sp. nov.; in macroconchs, the tubercles are clearly reinforced. Finally, $C$. curnieri is more recent, from the Olcostephanus jeannoti Subzone, and mostly in the Lyticoceras nodosoplicatum Zone (Ropolo, 1992; Bulot, 1995).

\section{C. claveli sp. nov. is very close to $C$. jurensis, with an adult size that could be comparable on} the basis of our current data. The coiling is identical between the two species. Ontogenically, the stages are on average shorter in $C$. claveli sp. nov. (stage 1: $9 \mathrm{~mm}$ vs. $15-20 \mathrm{~mm}$; stage 2: 45-50 mm vs. 50-55 mm; stage 3: 95-115 mm vs. 110-130 mm). Both species are trituberculate at stage 3, from roughly the same diameter. In C. claveli sp. nov., the ornamentation is generally less regular, with slightly more flexuous ribs. Rib bifurcations at the umbilical tubercle (fasciculation) are only exceptional in $C$. jurensis. Unlike $C$. claveli sp. nov., we do not observe in $C$. jurensis the peculiar appearance of the periventral tubercles which encompass several ribs so as to form a fibula, although they are nodular in both species. Rib bifurcations on the upper flanks of the adult body chamber (stage 4) are rare in the both species. Finally, C. jurensis is older than C. claveli sp. nov. (late Acanthodiscus radiatus Zone). 
596

597

598

599

600

601

602

603

604

605

606

607

608

609

610

611

612

613

614

615

616

617

618

619

620

C. claveli sp. nov. has certain affinities with $C$. heterocostatus $(=C$. primitivus $)$. However, some specimens of $C$. heterocostatus present a marked uncoiling of the body chamber, which gives them a general elliptical shape (aspinoceratic, see Reboulet, 1996, pl. 24, fig. 1); this is never the case in $C$. claveli sp. nov. whether in micro- or macroconch specimens. The ontogeny of $C$. heterocostatus is different, with a single trituberculate stage (stage 1) longer in the innermost whorl (20-30 mm vs. $9 \mathrm{~mm})$, whereas in C. claveli sp. nov. the lateral tubercle comes back at stage 3 to be well expressed in the adult body chamber. Ornamentally speaking, in $C$. heterocostatus the fasciculate pattern of stage 2 is made with bundles of usually two ribs starting from the umbilical tubercle. But unlike $C$. claveli sp. nov. in which we also recognize this tendency, in $C$. heterocostatus these tubercles show a characteristic lengthening in the direction of the rib that carries it (character known in the 'Sarasinella' Uhlig, 1905 of the late Valanginian - see Reboulet, 1996, p. 170). C. heterocostatus shows more radial ribs than in $C$. claveli sp. nov., but also more bifurcations of the ribs on the top of the flanks at stage 4 'adult' (without being numerous). Ornamentation is interrupted at the siphonal edge, even at stage 4 (except in putative macroconchs), unlike C. claveli sp. nov. where all the ribs systematically pass over the ventral area on the body chamber. Both species, as well as $C$. loryi, show the duplications of the main ribs on the adult body chamber (stage 4). C. claveli sp. nov. consistently has long and developed spines from all tubercles, which does not appear to be the case in $C$. heterocostatus. Finally, $C$. heterocostatus is older than $C$. claveli sp. nov., since this species is recorded in the late Valanginian Criosarasinella furcillata Zone.

The relatively open coiling with a fairly low growth in whorl height known in $D$. coniferus, associated with the total absence of fasciculation and the constant trituberculation of the main ribs throughout ontogeny, which are regularly interspersed with numerous smooth ribs, 
621

622 belongs.

623

624

625

626

627

628

629

630

631

632

633

634

635

636

637

638

639

640

641

642

643

644

645 analysis.

discard this species from the genus Crioceratites stricto sensu to which C. claveli sp. nov.

\section{Biometric and statistical analyzes of Crioceratites claveli sp. nov.}

\subsection{Univariate and bivariate analyses}

The three histograms H/D, U/D and U/H (Fig. 13) of the univariate analysis are clearly unimodal, relatively symmetrical and agree with a normal distribution (Shapiro-Wilk tests respectively of $\mathrm{W}=0.9823, p=0.8215 ; \mathrm{W}=0.9705, p=0.4585$ and $\mathrm{W}=0.9793, p=0.7359)$ : the assumption of the homogeneity of the sample is not challenged on the basis of the univariate

In the framework of the bivariate analysis (Fig. 14), the regression curves of the relations between $\mathrm{H}$ and $\mathrm{U}$ as a function of $\mathrm{D}$ show an harmonic growth according to the function $Y=b D^{a}$, with $a$ significantly different from $1(p<<0.05)$, indicating an allometric growth of the shell. The dispersion is low around the mean (coefficients of determination $\mathrm{R}^{2}>0.98$ ): the results are therefore very significant and the hypothesis of the homogeneity of the sample is reinforced (one single growth curve). However, we observe a slight disparity in the plot distribution between microconch and macroconch specimens on the diagrams for the values of $U$ (mainly $U / H$ ), with a cluster associated with the high values of $U / D$ and $U / H$ in the microconchs. This latter ratio was recommended by Marchand (1986) to detect a possible bimodality associated with sexual dimorphism. In ammonites, dimorphism is generally characterized by a difference in coiling between the antidimorphs: at the acquisition of sexual maturity, and at equivalent diameter, the microconch generally has a more open umbilicus due 
646

647

648

649

650

651

652

653

654

655

656

657

658

659

660

661

662

663

664

665

666

667

668

669

670

to the decreasing whorl height from its dorsal edge. Here, this feature is very weak and was not highlighted by the descriptive analysis only; this shows the importance to perform a biometric analysis whenever possible.

The $h=f(D)$ diagram shows a very strong linear increase in the spiral hiatus as a function of the diameter, but the dispersion is important $\left(\mathrm{R}^{2}=0.68\right)$, which shows the great variability of this parameter.

The Nt/2 and $\mathrm{Ni} / 2$ diagrams show a relative stability in the number of ribs per half-whorl during growth, although this parameter is extremely variable (large dispersion around the mean curve).

\subsection{Multivariate analysis}

A Principal Component Analysis (PCA - Fig. 15) was performed. The parameters h and Nt/2 have a distribution that significantly departs from normality (grayed out in Table 3). The Dornik and Hansen omnibus test shows departure from normality for the data taken as a whole $(p<<0.05)$, which requires the log transformation of the data to practice the PCA in order to normalize their distribution, reduce heteroscedasticity and resolve the problem of non-additivity of the independent variables, without modification of the variance. The correlation matrix was therefore used in order to standardize the data.

The first 3 principal components of the PCA have an eigenvalue close or greater than $1(4.05$, 1 and 0.95 ), and they retain $85.72 \%$ of the total inertia of the variance (Table 4), of which 72.17\% for PC1 and PC2 alone. The analysis is therefore considered relevant. The results are shown in Figure 15 and Table 5. The ornamentation vectors are orthogonal to the shell morphological vectors, indicating an apparent lack of correlation between these vector groups, as previously recognized for some other Crioceratites (Ropolo, 1995; Bert, 2014a). The 
diagram also shows an inverse correlation between H/D and the other morphological parameters: the relative height decreases as a function of (1) the diameter of the shell, (2) the opening of the umbilicus and (3) the spiral hiatus. These correlations are consistent with the descriptive analysis and to what is expected under the intraspecific laws in ammonites (Bert, 2014a), even considering the lack of $\mathrm{W}$ data. In contrast, the PCA diagram shows an inverse relationship between the number of primary and secondary ribs, which was not demonstrated by descriptive analysis; this apparent relationship needs to be tested (see below the correlation by Spearman rank).

The convex hulls formed by the antidimorphs recognized during descriptive analysis overlap widely. Even though the distribution of plots shows that macroconchs are more influenced by PC1 than microconchs, the distinction observed in bivariate analysis (Fig. 14) with respect to the high values of $\mathrm{U} / \mathrm{H}$ and $\mathrm{U} / \mathrm{D}$ in microconchs is not found in the plot distribution on the PCA (Fig. 15). This lack of graphic discrimination is essentially due to the fact that the U/H and U/D vectors have the same orientation as the $\mathrm{D}$ and $\mathrm{h}$ vectors, which favors the superposition of the plots associated with the microconchs with those of the large macroconchs. Thus, the largest positive values of the parameters related to the size (D and h) override the parameters related to the opening of the umbilicus. On PC2, on the other hand, the microconchs are even more influenced than the macroconchs by the ornamental parameters. Indeterminate antidimorphs form a group opposed to the D vector, which is logical since only very small specimens are affected by this group (see reasons in descriptive section, Chapter 5).

In addition to the PCA, a correlation test by Spearman rank (rs) was performed in order to verify and quantify the relationships between the variables. The results (Table 6 and Fig. 15) confirm the descriptive analysis and partially the PCA; they clearly show for this group of 
697

698

699

700

701

702

703

704

705

706

707

708

709

710

711

712

713

714

715

716

717

718

719

720

Crioceratites that the ornamental parameters are independent from the shell morphological parameters (non-covariant factors - see also Bert, 2014b, p. 234). The analysis of the PCA alone could suggest that the number of main tuberculate ribs would be inversely correlated with the number of smooth ribs, but this point is not confirmed by the correlation by Spearman rank ( $\mathrm{rs}=0.0099851 ; p=0.96764)$. Ornamental parameters also do not depend on the diameter.

On the other hand, the strong correlation between the morphological parameters of the shell (including the spiral hiatus $\mathrm{h}$ ) and the diameter is confirmed; it is positive in all cases except for the relative height, which decreases proportionally with the size.

The frequency histogram on PC1 is unimodal and normal ( $\mathrm{W}=0.9734, p=0.5242-$ Fig. 15). In contrast, the histogram attached to PC2 is clearly not normal (W=0.9095, $p=0.006)$. The explanation lies to the fact that the two dimorphs are well discriminated by the analysis, even if they do not stand out very clearly graphically on the PCA, whose distribution of points is rather homogeneous.

The morphological differences between the antidimorphs recognised by the descriptive analysis were statistically tested by an analysis of similarity (ANOSIM, Hammer and Harper, 2006 - Table 7) with 100,000 permutations. This non-parametric test is more suitable for small samples than a multivariate non-parametric analysis of variance (NPMANOVA Anderson, 2001). To ensure the homoscedasticity between the variables, they were standardized to mean zero and unit standard deviation (Quinn and Keough, 2002, p. 415). Our data are standardized measures, thus Euclidean distance was used to perform the ANOSIM (Quinn and Keough, 2002, p. 409). Pairwise comparison was performed only as a post hoc test (in case of $p<0.05$ ) with sequential Bonferroni significance of pairwise comparison $p$ values (Table 8) in order to reduce type I errors (Hammer and Harper, 2006, p. 36). 
722 Consistently with the rest of the study, statistically significant differences were found between

723

724

725 the both recognized antidimorphs based on descriptive analysis, but logically not with the indeterminate group which acts somewhat as a control group.

\section{Intraspecific variation in Crioceratites claveli sp. nov.}

\subsection{Background on the laws of intraspecific variability in ammonites}

Ammonites shells are known to display a sometimes significant morphological intraspecific variability (see synthesis in De Baets et al., 2015). The laws of intraspecific variability in ammonites can be generalized (Bert, 2019) and relate to at least 8 potential factors of variation, separated into two categories:

- (1) Discontinuous variability:

- changes between sexual dimorphs can affect shell size, coiling, peristome appearance, ornamentation, or combinations;

- non-sexual polymorphism can concern a particular character (for example: supernumerary tubercle);

- fluctuating asymmetry results from the inability of species to absorb ecological stress during their development;

- dextrality/senestria is linked to chirality.

- (2) Continuous variability:

- variations in the rate of development modulate the expression of ontogeny (heterochronies) and can restructure the shell by simple shift if the stages involved are of sufficiently different morphologies (see synthesis in De Baets et al., 2015); 
- the secondary erasing of the ornamentation does not seem to depend on any other

intrinsic factor (probable role of the environment - see Bersac and Bert, 2012);

- variation in the coiling (heteromorphy) is unstable depending on the groups, and could also reflect the influence of the environment (Reboulet et al., 2005; Bert and Bersac, 2013);

- multipolar variation is one of the most important in ammonites. It results from the generalization in two $\left({ }^{2}\right)$ or three $\left(^{3}\right)$ poles of the historical law known as the '1st Buckman law' (Westermann, 1966) now outdated, which shows a correlation (to varying degrees and not always in the same direction) between the robustness of the ornamentation, the thickness of the section, the height of the whorl and the opening of the umbilicus; the extreme poles are interconnected by all the intermediaries. Other examples of multipolarity $\left(\right.$ order $^{8}$ ) have been described recently in the literature in the Crioceratitidae Balearites Sarkar, 1954 / Pseudothurmannia Spath, 1923 (Matamales-Andreu and Company, 2019), but they arise from problems of interpretation by nesting discontinuous (non-sexual polymorphism concerning a supernumerary tubercle) and continuous factors (heteromorphy and 'classic' multipolar variation of order $\left.^{2}\right)$.

These different factors of variation may or may not be expressed simultaneously and be covariant with each other (example of morphological-dependent heterochronies - Bert, 2014a). A few exceptional cases seem to deviate from these laws: the significant anarchic variation of Cheloniceras cornuelianum (d'Orbigny, 1841) (Douvilleiceratidae Parona and Bonarelli, 1897) from the lower Aptian of the Argiles à Plicatules Formation (Bersac and Bert, 2018), can be explained by the context of exceptional environmental stress in connection with the Oceanic Anoxic Event 1a (OAE1a - Schlanger and Jenkyns, 1976; Arthur et al., 1985; and see discussion in Bersac and Bert, 2018). Subsequently, the Douvilleiceras de Grossouvre, 1894 took up a classic multipolar variation (Courville and Lebrun, 2010). 
In the case of the Crioceratites, the observed variability relates to dimorphism, multipolar variation and heterochronic variation. Significant variations in the type of coiling, such as for example in $C$. curnieri (see Ropolo, 1992) have not been observed in $C$. claveli sp. nov.

\subsection{Laws of intraspecific variability applied to C. claveli sp. nov.}

\subsubsection{Dimorphism}

The study of abundant material of $C$. claveli sp. nov. (this work) made it possible to highlight the presence of two distinct morphologies, interpreted here as sexual dimorphs (for example, compare Figs. 7a-b, 8 versus Figs. 7c-d, 12a-b). Both the two antidimorphs are present on the same sites studied, in the same samples, have the same stratigraphic distribution, present the same ornamental characteristics, substantially the same characteristics of shell morphology and above all have the same ontogenetic succession (except for heterochronic variations). This dimorphism was clearly recognized in the descriptive analysis based on the diameter reached by the different ontogenic stages by the two antidimorphs. Biometrics (bivariate analysis - Fig. 14) and statistical analyzes (ANOSIM - Table 7) subsequently made it possible to reinforce this result and to highlight small differences in construction concerning the relative umbilicus (U/H and U/D), not detected by the descriptive analysis alone: at equivalent diameter, the microconchs have values of these parameters very slightly higher than those of the macroconchs. Note that before the end of ontogenic stage 2, at an average of about $45 \mathrm{~mm}$ in diameter, it is not possible to discriminate the antidimorphs. Without taking into account individuals which are too small (1/3 of the sample) the observed sex ratio seems close to $50 \%$. Based on our study sample, the size ratio shows that macroconchs are on average around twice the size of microconchs. This order of magnitude is relatively consistent 
with that observed in C. loryi (compare Fig. 6a and c). These results confirm those obtained by Ropolo (1995) who had already recognized the existence of a dimorphism in Crioceratites, including C. loryi and C. curnieri among others, and the work of Reboulet (1996) which seemed to show its existence in $C$. heterocostatus ( $=C$. primitivus in Reboulet, 1996). The microconch dimorph has so far not been clearly demonstrated in $C$. jurensis due to a lack of specimens. By comparison with related species (C. claveli sp. nov., C. loryi, $C$. curnieri and probably also $C$. heterocostatus), where it is known, the existence of dimorphism in this species is highly probable on the same way.

\subsubsection{Multipolar variation}

The inverse relationship between relative height (H/D) and relative umbilicus (U/D) has been well demonstrated by multivariate analysis (Fig. 15; Table 6). This relationship is usually known as the Buckman's 1st law of variation; it is common to most ammonites and represents one aspect of the classical continuous multipolar variation (Bert, 2014a). There is also some variation in the strength and density of the ornamental pattern: the more slender specimens have markedly less rib differentiation with very inconspicuous tubercles. On the other hand, the multivariate analysis shows an absence of correlation between the ornamental parameters and the morphology of the shell.

Despite of this, continuous variation in C. claveli sp. nov. looks to be of the dipolar type $\left(\operatorname{order}^{2}\right.$ ), even if caution is required because of the lack of parameters based on the values of $\mathrm{W}$ in the analysis (this work). However, it is clear that the importance of $\mathrm{W}$ in the intraspecific variation in Crioceratites has never been highlighted in the literature.

\subsubsection{Heterochrony}


822 While the appearance diameter of the ornamental stages does not seem to depend on the 823 morphological parameters of the shell in $C$. claveli sp. nov., this is not the same for the 824 heterochronic variation. It was observed in the descriptive analysis, at least in the 825 microconchs, that the appearance of trituberculation of stage 3 during ontogeny is slightly 826 fluctuating and depends on the robustness of the ornamentation. Ontogeny is slightly delayed 827 for robust specimens and slightly accelerated for slender specimens.

828

\section{Biostratigraphic implications}

830

The discovery of $C$. claveli sp. nov. and the new understanding of the stratigraphic repartition of $C$. loryi, lead us to propose some changes in the biostratigraphic chart currently admitted for the early Hauterivian. This proposal for the south-eastern France may have extension potential for the Mediterranean Province of the Mediterranean Caucasian Subrealm (Tethyan Realm).

Crioceratites claveli Zone (new)

Index species. Crioceratites claveli sp. nov.

Reference section. The Cheiron ravine (CHE, see Chapter 4.1) in the Castellane area

840 (southeastern France, Vocontian Basin) with the beds interval 179-212. This interval is 841 correlable to the bundle comprising the beds 219-241e of the La Charce-Pommerol sections 842 (see Chapter 4.2 and Aguirre-Urreta et al., 2019, fig. 8). Note that at La Charce, the bed 843 succession is disturbed by a slump at the boundary between the $C$. claveli (new) and $L$. nodosoplicatum zones. 
Status. The finding of $C$. claveli sp. nov. in a stratigraphic position that was once considered to be the first acme of $C$. loryi, gives rise to some reflections since it appears that $C$. claveli sp. nov. is de facto the base marker of the current $C$. loryi Zone (for example see Bulot, 1995; Reboulet, 1996). Note that $C$. claveli sp. nov. shows a vertical distribution widely beyond its FO, since it extends to the second acme of the genus (at the top part of the current $C$. loryi Subzone; see Reboulet, 1996 for the quantitative approach of the 2 acmes). C. loryi does not exist at the base of its current zone and it only appears during the second acme of the genus, to disappear a short time later.

These findings allow us to propose the new $C$. claveli Zone instead of the $C$. loryi Zone for the Vocontian Basin (Table 9). Its lower limit is defined by the First Appearance Datum (FAD) of C. claveli sp. nov. and it upper limit by the FAD of L. nodosoplicatum (in the Cheiron reference section the FO of $C$. claveli sp. nov. is recorded in bed 179 , and in the bed 219 of the La Charce and Pommerol sections). This proposal has the advantage of avoiding any possible confusion between the former $C$. loryi Zone and a new definition that the revision of the stratigraphic distribution of its index species would have led.

The stratigraphic distribution of $C$. claveli sp. nov. is precisely known, and because of its high frequency (mainly in pelagic deposits; there apparent absence from the peri-Vocontian platform borders are due to lacks in the deposits - see Bulot, 1995, p. 93-94) it is a serious and legitimate candidate to the status of index species. Its potential for long-distance correlations has now to be tested outside the Vocontian Basin, but its presence is also attested in Italy (Faraoni et al., 1997 and see descriptive section in Chapter 5).

Faunal assemblage. See below for the new C. claveli Subzone, and Reboulet (1996, fig. 23) and Aguirre-Urreta et al. (2019, fig. 8) for the O. jeannoti Subzone.

\section{Crioceratites claveli Subzone (new)}


Index species. Crioceratites claveli sp. nov.

Reference section. The Cheiron ravine (CHE, see Chapter 4.1) in the Castellane area (southeastern France, Vocontian Basin), with the beds interval 179-197. This interval is correlable to the bundle of beds 219-231 of the la Charce-Pommerol sections (see Chapter 4.2 and Aguirre-Urreta et al., 2019, fig. 8).

Status. For the same reasons as for the new $C$. claveli Zone, it is necessary to replace the $C$. loryi Subzone with the new $C$. claveli Subzone. Its lower limit is defined by the FAD of $C$. claveli and its upper limit by the FAD of $O$. jeannoti. Within the new $C$. claveli Subzone of the Cheiron ravine and the La Charce-Pommerol sections, certain beds or bundles of beds are noticeably rich in representatives of the genus Crioceratites. We propose to recognize them as interval horizons; they are as follows:

- (1) the C. claveli lower interval Horizon (CC1 in Fig. 2): at the Cheiron ravine, it is represented by the bed 179 (= bed 219 in the La Charce-Pommerol sections), of which the lower limit is the First Occurrence (FO) of C. claveli. This horizon corresponds to the first acme of the genus Crioceratites evoked previously;

- (2) the C. claveli upper interval Horizon (CC2 in Fig. 2): at the Cheiron ravine, it is represented by the beds 194 and 195 (their exact correspondence in the La Charce-Pommerol sections is not yet clear, probably arround the bed 229). The latter is the bed with the Last Occurrence (LO) of C. claveli sp. nov.;

- (3) the C. loryi interval Horizon (CL in Fig. 2): at the Cheiron ravine, it is represented by the beds 196 (containing the FO of $C$. loryi) and 197 (= beds 230-231 in the La Charce-Pommerol sections).

Both the upper $C$. claveli and $C$. loryi interval horizons represent the second acme of the genus Crioceratites evoked previously. 
894

895

896

897

898

899

900

901

902

903

904

905

906

907

908

909

910

911

912

Faunal assemblage. $C$. claveli sp. nov. dominates largely the ammonite faunas of both the two $C$. claveli lower and upper interval horizons. The index species is present but rarer in the rest of its zone, especially compared to Neolissoceras grasianum for example. The other ammonites found is the subzone are (Fig. 2): Phyllopachyceras winkleri (Uhlig, 1882), Ph. infundibulum (d'Orbigny, 1841), Hypophylloceras tethys (d'Orbigny, 1841), Protetragonites cf. quadrisulcatus (d'Orbigny, 1841), Olcostephanus sayni (Kilian, 1896), Spitidiscus meneghinii, Bochianites kiliani Turner, 1962, Himantoceras sp., Oosterella sp. and Saynella aff. clypeiformis (d'Orbigny, 1841). In the $C$. loryi interval Horizon, the latter species replaces C. claveli sp. nov. and dominates largely the ammonite fauna. We can also notice the presence of Lyticoceras sp. nov., Valdedorsella sp. and Davouxiceras aff. sablieri (Astier, 1851).

\section{Conclusions}

(1) The research carried out in the Lower Cretaceous series of south-eastern France (Vocontian Basin) made it possible to highlight the two acmes of the genus Crioceratites during the former $C$. loryi Zone (early Hauterivian), so far reported to the single species $C$. loryi. The first acme marks the beginning of the zone and was considered to correspond more or less to the appearance of the genus Crioceratites in the early Hauterivian despite the existence of older representatives of this genus in the late Valanginian (Reboulet, 1996). However, only Crioceratites of the 2 nd acme were depicted in the literature. The new material from the classic Cheiron ravine site (Alpes de Haute-Provence), as well as the revision of the material cited by Reboulet (1996) from the former C. loryi Zone of the La Charce (Hauterivian GSSP) and Pommerol (Drôme) reference sections, revealed that only part of the second acme actually belongs to C. loryi. The Crioceratites from the interval between the first acme and the first part of the second acme belongs to C. claveli sp. nov. only 
919

920

921

922

923

924

925

926

927

(including the specimen of $C$. sp. depicted by Faraoni et al., 1997); $C$. claveli sp. nov. and $C$. loryi relay each other in the stratigraphy. An interesting point is that $C$. claveli sp. nov. shows a great morphological and ornamental stability between its appearance and disappearance, while the shift to C. loryi seems particularly sudden.

(2) C. claveli sp. nov. and C. loryi are differentiated mainly by the duration of the ontogenic stages reached during growth and by the presence of a marked spiny trituberculation in $C$. claveli sp. nov. The abundant material from the C. claveli lower interval Horizon (the first acme) allowed a detailed analysis of the variation of this species for a very short period of time (avoiding time-averaging). Under the laws of intraspecific variability in ammonites, 3 factors are currently known in C. claveli sp. nov.:

- the dimorphism has been recognized by palaeontological analysis (description of the both macro- and microconch morphs), biometry (discrimination of the both dimorphs on the U/D and H/D crossplots) and statistics (ANOSIM and pairwise comparison). The observed sex ratio is around $50 \%$;

- the multipolar variation of order $^{2}$ with an inverse correlation between the relative height and the relative umbilicus between two poles (morphological parameters) corresponds only partially to the classic Buckmann's 1st law of covariation since the robustness of the ornamentation (ornamental parameter) is here independent from the shell morphological parameters (non-covariant factors);

- the heterochronies concern the onset diameters of the ontogenic stages depending on the robustness of the ornamentation but not on the morphological parameters of the shell (ontogeny is slightly delayed for robust specimens and slightly accelerated for slender specimens). 
944

945

946

947

948

949

950

951

952

953

954

955

956

957

958

959

960

961

962

963

964

965

966

967

968

(3) The analysis of the stratigraphic distribution of $C$. claveli sp. nov. and $C$. loryi leads us to propose the new $C$. claveli Zone and Subzone to replace the $C$. loryi Zone and Subzone for the south-east of France. This proposal seems preferable to avoid a revision of the C. loryi Zone, which would lead to confusion with its current definition. Three interval horizons are recognized: the $C$. claveli lower interval Horizon (= the first acme of the Crioceratites); the $C$. claveli upper interval Horizon (= the first part of the second acme of the Crioceratites, which corresponds with the $\mathrm{LO}$ of $C$. claveli sp. nov.); and the $C$. loryi interval Horizon (= the second part of the second acme of the Crioceratites, which corresponds with the FO of $C$. lori). The presence of C. claveli sp. nov. at least in France (this work) and Italy (Crioceratites sp. in Faraoni et al., 1997) is a first step towards a generalization of this zonal proposal for the Mediterranean Province of the Mediterranean Caucasian Subrealm (Tethyan Realm).

(4) The northern edge of the Provençal platform (neritic zone of the Arc de Castellane) delivered some Crioceratites s. str. from the top part of the A. radiatus Zone, thus reducing the gap between the older Crioceratites of the uppermost Valanginian and those of the new $C$. claveli Zone. The specimens collected all belong to the species $C$. jurensis, which is rehabilitated and revised in this work, making it possible to refuse its synonymy with Davouxiceras nolani as proposed by Sarkar (1955 - see also Klein et al., 2007, p. 70): the type of $C$. jurensis is figured here for the first time since the original drawing by Pictet and Campiche (1861).

\section{Acknowledgments}

The authors would thank all the persons that helped for the field sampling in the Cheiron ravine: Francesco Bariani, Rémi Marongiu( $†$ ) and Pierre-Jean Bernard (Departmental Council of the Alpes de Haute-Provence). The Réserve naturelle nationale géologique de Haute- 
969

970

971

972

973

974

975

976

977

978

979

980

981

982

983

984

985

986

987

988

989

990

991

992

993

994

995

Provence and the Department Prefecture provided the search authorizations in the protected area. Lionel Cavin is warmly acknowledged for his help to find the type specimen of Crioceratites jurensis and for sending us a cast. Fabienne Giraud is acknowledged for the sending of the cast and photos of the type specimen of Crioceratites loryi. Finally, we warmly thank both the two reviewers, Josep Anton Moreno-Bedmar and Yves Dutour, and the Associate Editor Marcin Machalski for their very constructive comments.

\section{Funding}

This work was supported by the Departmental Council of the Alpes de Haute-Provence, France.

\section{References}

Agassiz, L., 1846. Nomina systematica generum molluscorum tam viventium quam fossilium. In: Jent, Gassmann (Eds.), Nomenclator zoologicus, vol. 9, 98 pp.

Aguirre-Urreta, B., Martinez, M., Schmitz, M., Lescano, M., Omarini, L., Tunike, M., Kuhnert, H. Concheyro, A., Rawson, P. F., Ramos, V. A., Reboulet, S., Noclin, N., Frederichs, Th., Nickl, A.-L., Pälike, H., 2019. Interhemispheric radio-astrochronological calibration of the time scales from the Andean and the Tethyan areas in the Valanginian-Hauterivian (Early Cretaceous). Gondwana Research 70, 104-132, https://doi.org/10.1016/j.gr.2019.01.006

Anderson, M.J., 2001. A new method for non-parametric multivariate analysis of variance. Austral Ecology 26, $32-46$.

Arnaud, H., 2005. The South-East France Basin (SFB) and its Mesozoic evolution. Géologie Alpine, Série spéciale "Colloques et Excursions", 7, p. 5-28.

Arthur, M.A., Dean, W.E., Schlanger, S.O., 1985. Variations in the global carbon cycle during the cretaceous related to climate, volcanism, and changes in atmosphericCO2. In: Sundquist, E.T., Broecker, W.E. (Eds.), The carbon cycle and atmosphericCO2: natural variations archean to present. Geophysical monograph series, 32, pp. $504-529$. 
Astier, J.-E., 1851. Catalogue descriptif des Ancyloceras appartenant à l'étage Néocomien d'Escragnolles et des Basses-Alpes. Annales des sciences physiques et naturelles d'agriculture et d'industrie 3 (2), 435-456.

Bersac, S., Bert, D., 2012. Ontogenesis, variability and evolution of the Lower Greensand Deshayesitidae (Ammonoidea, Lower Cretaceous, Southern England): reinterpretation of literature data; taxonomic and biostratigraphic implications. Annales du Muséum d'Histoire naturelle de Nice 27, 197-270.

Bersac, S., Bert, D., 2018. Revision of the lower Aptian (Lower Cretaceous) ammonite species Cheloniceras cornuelianum (d'Orbigny, 1841). Annales de $\quad$ Paléontologie $104 \quad$ (1), $45-70$. https://doi.org/10.1016/j.annpal.2018.01.001.

Bert, D., 2014a. Factors of intraspecific variability in ammonites, the example of Gassendiceras alpinum (d'Orbigny, 1850) (Hemihoplitidae, Upper Barremian). Annales de Paléontologie 100 (3), 217-236.

Bert, D., 2014b. L'influence de la variabilité intraspécifique sur la taxinomie, la biostratigraphie et l'évolution des ammonites : une approche paléobiologique - Exemples pris dans le Jurassique supérieur et le Crétacé inférieur (Unpubl. PhD thesis). Université de Rennes 1, 736 pp.

Bert, D., 2019. Les lois de la variabilité intraspécifique chez les ammonites. Les cahiers de la Réserve Naturelle de Sainte-Victoire, numéro spécial congrés APF 2019, 12.

Bert, D., Berasc, S., 2013. Evolutionary patterns - tested with cladistics - and processes in relation to palaeoenvironments of the upper Barremian genus Gassendiceras (Ammonitina, Lower Cretaceous). Palaeontology 56 (3), 631-646.

Breistroffer, M., 1936. Révision de la faune Hauterivienne du Néron en Chartreuse (Isère). Travaux du Laboratoire de Géologie de la Faculté des Sciences de l’Université de Grenoble 18, 131-155.

Bruguière, J.-G., 1789. Encyclopédie méthodique : histoire naturelle des vers. Panckoucke ed., 555 pp.

Bulot, L., 1995. Les formations à ammonites du Crétacé inférieur dans le Sud-Est de la France (Berriasien à Hauterivien) : biostratigraphie, paléontologie et cycles sédimentaires (Unpubl. PhD thesis). Muséum National d'Histoire Naturelle de Paris, 375 pp.

Bulot, L., Thieuloy, J.-P., 1995. Les biohorizons du Valanginien su Sud-Est de la France: un outil fondamental pour les corrélations au sein de la Téthys occidentale. Géologie Alpine Mémoire Hors Série 20(1994), $15-41$.

Bulot, L., Thieuloy, J.-P., Blanc, E., Klein, J., 1993. Le cadre stratigraphique du Valanginien supérieur et de l'Hauterivien du Sud-Est de la France: définition des biochronozones et caractérisation de nouveaux biohorizons. 
Bulot, L., Thieuloy, J.-P., Arnaud, H., Delanoy, G., 1995. The Lower Cretaceous Cephalopod Team First Field Metting (Digne, 1990). Géologie Alpine Mémoire Hors Série 20(1994), 383-399.

Busnardo, R., Charollais, J.-J., Weidmann, M., Clavel, B., 2003. Le Crétacé inférieur de la Veveyse de Châtel

(Ultrahelvétique des Préalpes externes; canton de Fribourg, Suisse). Revue de Paléobiologie 22(1), 1-174.

Cotillon, P., 1971. Le Crétacé inférieur de l'arc subalpin de Castellane entre l'Asse et le Var - stratigraphie et sédimentologie. Bureau de Recherches Géologiques et Minières 68, 313.

Cotillon, P., Ferry, S., Gaillard, Ch., Jautée, E., Latreille, G., Rio, M., 1980. Fluctuation des paramètres du milieu marin dans le domaine Vocontien (France Sud-Est) au Crétacé inférieur : mise en évidence par l'étude des formations marno-calcaires alternantes. Bulletin de la Société Géologique de France 22(5), 735-744.

Courville, P., Lebrun, P., 2010. L’Albien (Crétacé) de la région de Troyes (Aube) et ses ammonites: Hoplitidae et Douvilleiceratidae. Fossiles 4, 6-30.

Cuvier, G., 1798. Tableau élémentaire de l'histoire naturelle des animaux. Baudouin imprimeur 662, 754.

De Baets, K., Bert, D., Hoffmann, R., Monnet, C., Yacobucci, M., Klug, Ch., 2015. Ammonoid intraspecific variability. In Klug, Ch. et al. (eds), Ammonoid Paleobiology : from anatomy to ecology. Topics in Geobiology 43, pp. 359-426, DOI 10.1007/978-94-017-9630-9_9.

Dimitrova, N., 1967. Les fossiles de Bulgarie. 4. Crétacé inférieur. Cephalopoda (Nautiloidea et Ammonoidea).

Faraoni, P., Flore, D., Marini, A., Pallini, G., Pezzoni, N., 1997. Valanginian and early Hauterivian ammonite

Ferry, S., 2017. Summary on Mesozoic carbonate deposits of the Vocontian Trough (Subalpine Chains, SE France). In Granier, B. (ed.), Some key Lower Cretaceous sites in Drôme (SE France). Carnets de Géologie, CG2017_B01,pp.9-42.

Gill, Th., 1871. Arrangement of the families of mollusks. Smithsonian Miscellaneous Collections 227, 49. Vocontian Trough: a strong obliquity control. Geological Society, London, Special Publications 85(1), $143-164$. 
Hammer, O., Harper, D. A. T., Ryan, P. D., 2001. PAST: Palaeontological Statistics Software Package for

1055

1056

1057

1058

1059

1060

1061

1062

1063

1064

1065

1066

1067

1068

1069

1070

1071

1072

1073

1074

1075

1076

1077

1078

1079

1080

1081

1082

1083

Education and Data Analysis. Palaeontologia Electronica 4(1), 9 pp.

Hoedemaeker, P.J., Reboulet, S., (reporters), Aguirre-Urreta, M.B., Alsen, P., Aoutem, M., Atrops, F., Barragán, R., Company, M., González Arreola, C., Klein, J., Lukeneder, A., Ploch, I., Raisossadat, N., Rawson, P.F., Ropolo, P., Vašíček, Z., Vermeulen, J., Wippich, M.G.E., 2003. Report on the 1st InternationalWorkshop of the IUGS Lower Cretaceous Ammonite Working Group, the "Kilian Group” (Lyon, 11 July 2002). Cretaceous Research 24, 89-94, and erratum p. 805.

Hyatt, A., 1899. Cephalopoda. In: Zittel, K. A. von (Ed.), (1896-1900), Textbook of Palaeontology. Transl. Eastman, C.R. Macmillan, pp. 502-604.

Kilian, W., 1896. Notice stratigraphique sur les environs de la région de Sisteron et contributions à la connaissance des terrains secondaires du Sud-Est de la France. Bulletin de la Société Géologique de France 23, $211-227$.

Kilian, W., 1910. Un nouvel exemple de phénomène de convergence chez des ammonitidés. Sur les origines du groupe de 1' «Ammonite bicurvatus » Mich. (sous-genre Saynella Kil.). Extrait des Comptes rendus des séances de l'Académie des Sciences 150, 150-153.

Kilian, W., Zürcher, Ph., avec la collaboration d'Adrien Guebhard, 1896. Notice sur la région d'Escragnolles (Alpes Maritimes). Bulletin de la Société Géologique de France 3(23), 952-969.

Klein, J., Busnardo, R., Company, M., Delanoy, G., Kakabadze, M.V., Reboulet, S., Ropolo, P., Vašíček, Z., Vermeulen, J., 2007. Lower Cretaceous Ammonites III. Bochianitoidea, Protancyloceratoidea, Ancyloceratoidea, Ptychoceratoidea. Fossilium Catalogus I : Animalia, vol. 144. Backhuys Publishers, p. 381.

Léveillé, Ch, 1837. Description de quelques nouvelles coquilles fossiles du Département des Basses-Alpes. Mémoires de la Société Géologique de France 2, 313-315.

Mandov, G. K., 1976. L'étage Hauterivien dans les Balkanides occidentales (Bulgarie de l'ouest) et sa faune d'ammonites. Annuaire de l’Université de Sofia, Livre 1, Géologie 67, 11-99.

Marchand, D., 1986. L'évolution des Cardioceratinae d'Europe occidentale dans leur contexte paléobiogéographique (Callovien supérieur-Oxfordien moyen) (Unpubl. PhD thesis). Université de Dijon, $601 \mathrm{pp}$.

Matamales-Andreu, R., Company, M., 2019. Morphological variability patterns in the BalearitesPseudothurmannia genera boundary (Ammonoidea, late Hauterivian): taxonomic and biostratigraphic implications. Journal of Systematic Palaeontology 17 (13), 869-895. 
Mayer-Eymar, K., 1887. Systematisches Verzeichniss der Kreide- und Tertiär-Versteinerungen der Umgegend von Thun, nebst Beschreibung der neuen Arten. Beiträge zur geologischen Karte der Schweiz, Beilage 24(2), $\mathrm{i}-\mathrm{xxviii}+1-128$.

Mutterlose, J., Rawson, P., Reboulet, S., Baudin, F., Bulot, L., Emmanuel, L., Gardin, S., Martinez, M., Renard,

M., 2020. The Global Boundary Stratotype Section and Point (GSSP) for the base of the Hauterivian Stage

Nolan, H., 1894. Note sur les Crioceras du groupe de Crioceras Duvali. Bulletin de la Société Géologique de

France 3(22), 183-196.

Orbigny, A. d', 1840-1842. Paléontologie française - Terrains crétacés - Tome 1, Céphalopodes (liv. 16).

Masson, pp. 121-430.

Paquier, V. L., 1900. Recherches géologiques dans le Diois et les Barronies orientales. Bulletin de la Société de

Statistique des Sciences Naturelles et des Arts industriels du Département de l'Isère 5, 77-476.

Parona, C.F., Bonarelli, G., 1897. Fossili albiani d'Escragnolles, del Nizzardo e della Ligura occidentale.

Paleontographia Italica 2, 53-112.

Pictet, F., Campiche, G., 1861. Description des fossiles du terrain Crétacé des environs de Sainte-Croix, part 2.

Quinn, G.P., Keough M.J., 2002. Experimental design and data analysis for biologists. Cambridge University

Press, $537 \mathrm{pp}$.

Reboulet, S., 1996. L'évolution des ammonites du Valanginien-Hauterivien inférieur du bassin Vocontian et de

la plate-forme provençale (Sud-Est de la France): relations avec la stratigraphie séquentielle et implications biostratigraphique. Documents des Laboratoires de Géologie de Lyon, 137, 371 pp.

Reboulet, S., 2015. Le Valanginien-Hauterivien inférieur du SE de la France. 2015, Livret-Guide des Excursions du Groupe Français du Crétacé, 74 pp.

Reboulet, S., Atrops, F., 1999. Comments and proposals about the Valanginian-Lower Hauterivian ammonite zonation of south-eastern France. Eclogae geologicae Helvetiae 92, 183-197. limite Valanginien-Hauterivien. Geobios 25(4), 469-476. 
Reboulet, S., Mattioli, E., Pittet, B., Baudin, F., Olivero, D., Proux, O., 2003. Ammonoid and nannoplankton abundance in Valanginian (early Cretaceous) limestone-marl successions from the southeast France Basin: carbonate dilution or productivity? Palaeogeography, Palaeoclimatology, Palaeoecology 201, 113-139.

Reboulet, S., Giraud, F., Proux, O., 2005. Ammonoid abundance variations related to changes in trophic conditions across the Oceanic Anoxic Event 1d (Latest Albian, SE France). Palaios 20, 121-141.

Reboulet, S., Hoedemaeker, Ph. J., Aguirre-Urreta, M., B., Alsen, P., Atrops, F., Baraboshkin, E., Y., Company,

M., Delanoy, G., Dutour, Y., Klein, J., Latil, J.-L., Lukeneder, A., Mitta, V., Mourgues, F. A., Ploch, I.,

Raisossadat, N., Ropolo, P., Sandoval, J., Tavera, J. M., Vašíček, Z., Vermeulen, J., Arnaud, H., Granier, B.,

Premoli-Silva, I., 2006. Report on the 2nd international meeting of the IUGS lower Cretaceous ammonite $712-715$.

Reboulet, S., Klein, J., (reporters), Barragán, R., Company, M., González-Arreola, C., Lukeneder, A.,

Raisossadat, S.N., Sandoval, J., Szives, O., Tavera, J.M., Vašíček, Z., Vermeulen, J., 2009. Report on the 3rd International Meeting of the IUGS Lower Cretaceous AmmoniteWorking Group, the "Kilian Group" (Vienna, Austria, 15th April 2008). Cretaceous Research 30, 496-502.

Reboulet, S., Rawson, P.F., Moreno-Bedmar, J.A., (reporters), Aguirre-Urreta, M.B., Barragán, R., Bogomolov,

Y., Company, M., González-Arreola, C., Idakieva Stoyanova, V., Lukeneder, A., Matrion, B., Mitta, V., Randrianaly, H., Vašíček, Z., Baraboshkin, E.J., Bert, D., Bersac, S., Bogdanova, T.N., Bulot, L.G., Latil, J.-L.,

Mikhailova, I.A., Ropolo, P., Szives, O., 2011. Report on the 4th International Meeting of the IUGS Lower

Cretaceous Ammonite Working Group, the "Kilian Group" (Dijon, France, 30th August 2010). Cretaceous Research 32, 786-793.

Reboulet, S., Szives, O., (reporters), Aguirre-Urreta, B., Barragán, R., Company, M., Idakieva, V., Ivanov, M.,

Kakabadze, M.V., Moreno-Bedmar, J.A., Sandoval, J., Baraboshkin, E.J., Çağlar, M.K., Fözy, I., González-

Arreola, C., Kenjo, S., Lukeneder, A., Raisossadat, S.N., Rawson, P.F., Tavera, J.M., 2014. Report of the 5th Turkey, 31st August 2013). Cretaceous Research 50, 126-137. 
Rodighiero, A., 1919. Il sistema Cretaceo del Veneto occidentale compresso fra l'Adige e il Piave con speciale riguardo al Neocomiano dei Setti Comuni. Palaeontographica Italica 25, 70-125.

Ropolo, P., 1992. Crioceratites curnieri nov. sp. une nouvelle espèce d'ammonite hétéromorphe préfigurant l'acquisition des coquilles triparties de l'Hauterivien inférieur (Ammonoidea, Ancyloceratina). Mésogée 51, $65-73$.

Ropolo, P., 1995. Implications of variation in coiling in some Hauterivian (Lower Cretaceous) heteromorph ammonites from the Vocontian basin, France. Memorie Descritivi della Carta Geologica d'Italia 51, 137-165.

Salvador, A., 1994. International stratigraphic guide: a guide to stratigraphic classification, terminology, and procedure, second ed. The Geological Society of America, Boulder, Colorado, p. 214.

Sarkar, S., 1954. Sur un genre nouveau d'ammonite déroulée. Compte Rendu Sommaire des Scéances de la Société géologique de France, 97-98.

Sarkar, S.S., 1955. Révision des ammonites déroulées du Crétacé inférieur du Sud-Est de la France. Memoires de la Société Géologique de France 34 (72), 1-176.

Schlanger, S. O., Jenkyns, H. C., 1976. Cretaceous oceanic anoxic events: causes and consequences. Geologie en Mijnbouw 55(3-4), 179-184.

Spath, L.F., 1923. In: Monograph of the Ammonoidea of the Gault, Vol. 1. Palaeontographical Society, pp. 1-72.

Steinmann, G., 1890. In: Steinmann, G., Doederlein, L. (Eds.), Elemente der Paläontologie, p. 848. Leipzig.

Thieuloy, J.-P., 1972. Biostratigraphie des lentilles à Pérégrinelles (Brachiopodes) de l'Hauterivien de Rotier (Drôme, France). Geobios, 5(1), 5-53.

Thieuloy, J.-P., 1977. La zone à callidiscus du Valanginien supérieur Vocontian (Sud-Est de la France).

Lithostratigraphie, ammonitologie, limite Valanginien-Hauterivien, corrélations. Géologie Alpine 53, 83-143.

Thieuloy, J.-P., Bulot, L.G., 1993. Ammonites du Crétacé inférieur du Sud-Est de la France: 1. Nouvelles espèces à valeur stratigraphique pour le Valanginien et l'Hauterivien. Géologie Alpine 68(1992), 85-103.

Turner, J., 1962. Quelques remarques sur les genres Bochianites d'Orbigny et Baculina d'Orbigny. Travaux du Laboratoire de Géologie de la Faculté des Sciences de Grenoble 38 : 241-248.

Uhlig, V., 1882. Zur Kenntnis der Cephalopoden der Rossfeldscichten. Jahrbuch der Kaiserlich-Königlichen Geologischen Reichsanstalt 32, 373-396.

Uhlig, V., 1905. Einige Bemerkungen über die Ammonitengattung Hoplites Neumayr. Sitzungsberichte der 
Vašíček, Z., 1995. Lower Cretaceous ammonite biostratigraphy in the Western Carpathians (the Czech and Slovak Republics). Géologie Alpine Mémoire Hors Série 20(1994), 169-189.

Vašíček, Z., 2005. The oldest (Late Valanginian) Crioceratitinae (heteromorphic ammonoids) from the Central Western Carpathians (Slovakia). Geologica Carpathica 56, 245-254.

Vermeulen, J., 2004. Vers une nouvelle classification à fondement phylogénétique des ammonites hétéromorphes du Crétacé inférieur méditerranéen. Le cas des Crioceratitidae Gill, 1871, nom. correct. Wright, 1952, des Emericiceratidae fam. nov. et des Acrioceratidae fam. nov. (Ancylocerataceae Gill, 1871). Riviéra Scientifique 88, 69-92.

Vernet, B., 2017. Etude de la coupe du Ravin du Cheiron (Unpubl. M2 thesis). Université de Rennes 1, 37 pp.

Westermann, G.E.G., 1966. Covariation and taxonomy of the Jurassic ammonite Sonninia adicra (Waagen).

Neues Jahrbuch für Geologie und Paläontologie Abteilung 124(3), 289-312.

Wiedmann, J., 1966. Stammesgeschichte und System der posttriadischen Ammonoideen. 2. Teil. Neues Jahrbuch für Geologie und Pal€aontologie, Abhandlungen 127, 13-81.

\section{Captions of the figures:}

Fig. 1. Palaeogeographic map of the Vocontian Basin for the Hauterivian (southeastern France, modified after Arnaud, 2005). The stars point out the sections mentioned in the text: CAR = Rougon; CHE $=$ the Cheiron ravine; COU1 = Bargème; ESC $=$ Escragnolles; $\mathrm{LCH}=$ La Charce GSSP $;$ POM = Pommerol; PV2 = La Paludsur-Verdon.

Fig. 2. Lithology of the Cheiron ravine (CHE) with ammonite fauna and biostratigraphy (this work). The interval horizons highlighted in this section are: $\mathrm{CC} 1=$ Crioceratites claveli lower interval Horizon; $\mathrm{CC} 2=$ Crioceratites claveli upper interval Horizon; $\mathrm{CL}=$ Crioceratites loryi interval Horizon.

1193 Fig. 3. Crioceratites jurensis (Nolan, 1894), cast of the type specimen MHNG GEPI 16787, section ESC, Acanthodiscus radiatus Zone. The arrow points out the end of the phragmocone.

1195 Fig. 4. Crioceratites jurensis (Nolan, 1894), specimen DBT.BC47, section CAR, upper part of the Acanthodiscus radiatus Zone; c is face B of the body chamber of the same specimen. The arrow points out the end of the phragmocone.

Fig. 5. Crioceratites jurensis (Nolan, 1894), specimen LCT.7Z, section PV2, upper part of the Acanthodiscus radiatus Zone. The arrow points out the end of the phragmocone. 
Fig. 6. Crioceratites loryi (Sarkar, 1955); a-b: macroconch specimen DBT.AV98 from the Moriez area; c-d: microconch specimen DBT.BB50 from the Moriez area; e: microconch specimen DBT.BB84 from CHE, bed 197. All the specimens are from the Crioceratites loryi interval Horizon in the new Crioceratites claveli Zone and Subzone. The arrows point out the end of the phragmocone.

Fig. 7. Crioceratites claveli sp. nov.; a-b: macroconch specimen DBT.BB48, holotype; c-d: microconch specimen DBT.BB49; e: microconch specimen DBT.BB65; f: microconch specimen DBT.BB60; g: microconch specimen DBT.BB57. All the specimens are from CHE, bed 179, in the C. claveli lower interval Horizon, new C. claveli Zone and Subzone. The arrows point out the end of the phragmocone.

Fig. 8. Crioceratites claveli sp. nov., macroconch specimen DBT.BB52, from CHE, bed 179, in the C. claveli lower interval Horizon, new C. claveli Zone and Subzone. The arrow points out the end of the phragmocone.

Fig. 9. Crioceratites claveli sp. nov.; a: macroconch specimen DBT.BB55; b-c: microconch specimen DBT.BB54, note the nodular periventral tubercles of the ontogenic stage 2. All the specimens are from CHE, bed 179, in the C. claveli lower interval Horizon, new C. claveli Zone and Subzone. The arrows point out the end of the phragmocone.

Fig. 10. Crioceratites claveli sp. nov., a: microconch specimen DBT.BG50; b: microconch specimen DBT.BG51; c: macroconch specimen DBT.BG75. All the specimens are from CHE, bed 195, in the C. claveli upper interval Horizon, new C. claveli Zone and Subzone. The arrows point out the end of the phragmocone.

Fig. 11. Crioceratites claveli sp. nov., macroconch specimen DBT.BG49, from CHE, bed 194, in the C. claveli upper interval Horizon, new C. claveli Zone and Subzone. The arrow points out the end of the phragmocone.

Fig. 12. Crioceratites claveli sp. nov.; a-b: microconch specimen POM 219.2 from POM, bed 219, b is the mould of the imprint; c: microconch specimen FSL 487733a; d: microconch specimen FSL 487743a; e: microconch specimen FSL 487733e; f: microconch specimen FSL 487733f; g: undetermined antidimorph specimen FSL 487733j. Specimens c-f are from LCH, in bed 219; specimen $\mathrm{g}$ is from bed 220 of the same section. All the specimens are from the $C$. claveli lower interval Horizon, new $C$. claveli Zone and Subzone. The arrows point out the end of the phragmocone.

Fig. 13. Diagrams of the univariate analysis. Normality curve in black, Kernel density in red (refer to the electronic version of the paper).

Fig. 14. Bivariate analysis crossplots. Red dots: microconchs; blue dots: macroconchs; black dots: undetermined antidimorphs (refer to the electronic version of the paper). 
1229 Fig. 15. Diagrams of the multivariate analysis: principal component analysis crossplot, 'loading' of the variables on the first two Principal Components, frequency histograms of the projections of the plots on the first two PC

1231 and matrix of the Spearman's rank correlation. Red dots: microconchs; blue dots: macroconchs; black dots: undetermined antidimorphs; normality curve in black, kernel density in red (refer to the electronic version of the paper).

\section{Caption of the tables:}

Table 1. Measurements of the main specimens of Crioceratites jurensis. In bold are the diameters expected 1237 adult.

1238 Table 2. Measurements of the main specimens of Crioceratites claveli sp. nov. In bold are the expected adult 1239 diameters.

1240 Table 3. Normality tests of the multivariate analysis.

1241 Table 4. Variance and eigenvalue reached by the principal components.

1242 Table 5. Loading of the variables on the 7 PC.

1243 Table 6. Correlation by Spearman rank. In grey: dependent variables $(\mathrm{p}<<0.05)$.

1244 Table 7. The ANOSIM.

1245 Table 8. $p$ value of the sequential Bonferoni significance: in grey are the significant differences.

1246 Table 9. Biostratigraphic chart. 


\begin{tabular}{|l|r|l|l|l|l|r|r|r|r|r|r|r|r|}
\hline No. specimen & \multicolumn{1}{l}{ D } & H & W & U & \multicolumn{1}{l}{ h } & Nt/2 & Ni/2 & H/D & W/D & U/D & W/H & U/H & Alpha \\
\hline & 139.78 & 33.20 & 35.50 & 79.62 & c16.00 & - & - & 0.24 & 0.25 & 0.57 & 1.07 & 2.40 & \\
MHNG GEPI 16787 - Fig. 3 & 88.00 & 24.70 & 19.34 & 44.58 & 5.22 & 8 & 30 & 0.28 & 0.22 & 0.51 & 0.78 & 1.80 & $170^{\circ}$ \\
\hline & 116.50 & 32.52 & 26.48 & 67.18 & 9.56 & 6 & 26 & 0.28 & 0.23 & 0.58 & 0.81 & 2.07 & \\
DBT.04171-CAR.BC47 - Fig. 4 4 & ph89.48 & 26.38 & 23.68 & 47.54 & 4.24 & - & - & 0.30 & 0.26 & 0.53 & 0.90 & 1.80 & $120^{\circ}$ \\
\hline & $\mathbf{1 5 5 . 3 4}$ & $\mathbf{4 2 . 1 0}$ & $\mathbf{3 9 . 6 1}$ & $\mathbf{8 4 . 6 4}$ & $\mathbf{c 1 3 . 0 0}$ & $\mathbf{7}$ & $\mathbf{3 8}$ & $\mathbf{0 . 2 7}$ & $\mathbf{0 . 2 6}$ & $\mathbf{0 . 5 5}$ & $\mathbf{0 . 9 4}$ & $\mathbf{2 . 0 1}$ & \\
& ph109.00 & 33.02 & 32.14 & 59.40 & 6.52 & - & - & 0.30 & 0.30 & 0.55 & 0.97 & 1.80 & $140^{\circ}$ \\
LCT.04144-PV2.7Z - Fig. 5 & 54.30 & 18.00 & - & 23.14 & 2.42 & 10 & - & 0.33 & - & 0.43 & - & 1.28 & $260^{\circ}$ \\
\hline DBT.04144-PV2.BG31 & $\mathbf{1 6 4 . 0 0}$ & $\mathbf{4 3 . 0 0}$ & $\mathbf{3 5 . 0 0}$ & $\mathbf{8 8 . 7 6}$ & $\mathbf{9 . 2 6}$ & - & - & $\mathbf{0 . 2 6}$ & $\mathbf{0 . 2 1}$ & $\mathbf{0 . 5 4}$ & $\mathbf{0 . 8 1}$ & $\mathbf{2 . 0 4}$ & \\
\hline
\end{tabular}




\begin{tabular}{|c|c|c|c|c|c|c|c|c|c|c|c|c|c|c|}
\hline No. specimen & Dimorph & D & $\mathbf{H}$ & $\mathbf{W}$ & $\mathbf{U}$ & h & $\mathrm{Nt} / 2$ & $\mathrm{Ni} / 2$ & H/D & W/D & U/D & W/H & U/H & Alpha \\
\hline \multirow{6}{*}{$\begin{array}{l}\text { DBT.04039-CHE/179.BB } 48- \\
\text { Fig. 7a-b }\end{array}$} & \multirow{6}{*}[\mathrm{M}]{} & 115.00 & 30.84 & 19.90 & 58.20 & 5.30 & 6 & 30 & 0.27 & 0.17 & 0.51 & 0.65 & 1.89 & \\
\hline & & 98.00 & 27.54 & & 50.60 & 6.40 & & & 0.28 & & 0.52 & & 1.84 & $90^{\circ}$ \\
\hline & & \begin{tabular}{|l|}
77.82 \\
\end{tabular} & 25.34 & & 35.60 & 1.60 & & & 0.33 & & 0.46 & & 1.40 & $90^{\circ}$ \\
\hline & & \begin{tabular}{|l|}
64.20 \\
\end{tabular} & 19.38 & & 28.68 & 1.30 & 6 & 32 & 0.30 & & 0.45 & & 1.48 & $90^{\circ}$ \\
\hline & & \begin{tabular}{|l|}
50.52 \\
\end{tabular} & 17.08 & & 22.00 & 0.90 & 7 & 35 & 0.34 & & 0.44 & & 1.29 & $90^{\circ}$ \\
\hline & & \begin{tabular}{|l|}
43.50 \\
\end{tabular} & 16.18 & & 16.58 & 0.10 & & & 0.37 & & 0.38 & & 1.02 & $90^{\circ}$ \\
\hline \multirow{2}{*}{$\begin{array}{l}\text { DBT.04039-CHE/179.BB49- } \\
\text { Fig. 7c-d }\end{array}$} & \multirow{2}{*}[\mathrm{m}]{} & 78.30 & 24.00 & 16.18 & 38.50 & 3.20 & 6 & 32 & 0.31 & 0.21 & 0.49 & 0.67 & 1.60 & \\
\hline & & 60.00 & 20.84 & 12.76 & 28.20 & 0.00 & & & 0.35 & 0.21 & 0.47 & 0.61 & 1.35 & $90^{\circ}$ \\
\hline DBT.04039-CHE/179.BB51 & {$[\mathrm{m}]$} & 43.88 & 14.22 & & 19.42 & 1.10 & 0 & 37 & 0.32 & & 0.44 & & 1.37 & \\
\hline $\begin{array}{l}\text { DBT.04039-CHE/179.BB52 - } \\
\text { Fig. } 8\end{array}$ & {$[\mathrm{M}]$} & 140.20 & 41.30 & & 68.00 & 6.14 & 6 & 38 & 0.29 & & 0.49 & & 1.65 & \\
\hline \multirow{2}{*}{ DBT.04039-CHE/179.BB53 } & \multirow{2}{*}[\mathrm{m}]{} & 42.98 & 15.56 & & 18.68 & 1.80 & 9 & 28 & 0.36 & & 0.43 & & 1.20 & \\
\hline & & 34.72 & 13.88 & & 13.44 & 0.60 & 9 & 30 & 0.40 & & 0.39 & & 0.97 & $90^{\circ}$ \\
\hline $\begin{array}{l}\text { DBT.04039-CHE/179.BB54 - } \\
\text { Fig. 09b-c }\end{array}$ & {$[\mathrm{m}]$} & 56.84 & 19.40 & & 26.76 & 1.98 & 10 & 28 & 0.34 & & 0.47 & & 1.38 & \\
\hline $\begin{array}{l}\text { DBT.04039-CHE/179.BB55a } \\
\text { - Fig. 09a }\end{array}$ & {$[\mathrm{M}]$} & 75.40 & 26.60 & & 31.36 & 2.22 & 9 & 40 & 0.35 & & 0.42 & & 1.18 & \\
\hline DBT.04039-CHE/179.BB56 & {$[\mathrm{M}]$} & 111.74 & 34.30 & 20.70 & 57.64 & 6.14 & & & 0.31 & 0.19 & 0.52 & 0.60 & 1.68 & \\
\hline $\begin{array}{l}\text { DBT.04039-CHE/179.BB57 - } \\
\text { Fig. } 7 \mathrm{~g}\end{array}$ & {$[\mathrm{~m}]$} & 47.24 & 16.66 & & 18.98 & 1.18 & 9 & 51 & 0.35 & 2 & 0.40 & & 1.14 & \\
\hline DBT.04039-CHE/179.BB58 & {$[\mathrm{M}]$} & 47.18 & 15.38 & & 19.42 & 2.42 & & & 0.33 & & 0.41 & & 1.26 & \\
\hline DBT.04039-CHE/179.BB59 & {$[\mathrm{m}]$} & 48.94 & 15.60 & & 22.24 & 1.66 & 9 & 39 & 0.32 & 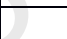 & 0.45 & & 1.43 & \\
\hline $\begin{array}{l}\text { DBT.04039-CHE/179.BB60 - } \\
\text { Fig. 7f }\end{array}$ & {$[\mathrm{m}]$} & 66.00 & 23.30 & & 29.30 & 2.35 & & 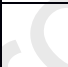 & 0.35 & & 0.44 & & 1.26 & \\
\hline DBT.04039-CHE/179.BB64 & $?$ & 24.30 & 8.94 & & 9.22 & & 7 & 44 & 0.37 & 0.00 & 0.38 & & 1.03 & \\
\hline $\begin{array}{l}\text { DBT.04039-CHE/179.BB65 - } \\
\text { Fig. } 7 \mathrm{e}\end{array}$ & {$[\mathrm{m}]$} & 38.34 & 13.58 & 8.70 & 17.00 & 1.40 & 7 & 47 & 0.35 & 0.23 & 0.44 & 0.64 & 1.25 & \\
\hline $\begin{array}{l}\text { DBT.04039-CHE/194.BG49-- } \\
\text { Fig. } 11\end{array}$ & {$[\mathrm{M}]$} & 159.00 & 44.32 & & 87.76 & & & & 0.29 & & 0.55 & & 1.98 & \\
\hline $\begin{array}{l}\text { DBT.04039-CHE/195.BG50 - } \\
\text { Fig. 10a }\end{array}$ & {$[\mathrm{m}]$} & 78.38 & 23.30 & & 37.00 & 3.50 & 9 & 24 & 0.30 & & 0.47 & & 1.59 & \\
\hline $\begin{array}{l}\text { DBT.04039-CHE/195.BG51 - } \\
\text { Fig. } 10 \mathrm{~b}\end{array}$ & {$[\mathrm{~m}]$} & 85.54 & 25.62 & & 40.06 & 3.84 & & & 0.30 & & 0.49 & & 1.56 & \\
\hline DBT.04039-CHE/195.BG58 & {$[\mathrm{M}]$} & 133.16 & 39.50 & & 66.44 & 5.44 & 8 & 34 & 0.30 & & 0.50 & & 1.68 & \\
\hline DBT.04039-CHE/195.BG59 & {$[\mathrm{m}]$} & 61.12 & 19.32 & & 27.60 & 3.06 & 9 & 29 & 0.32 & & 0.45 & & 1.43 & \\
\hline DBT.04039-CHE/195.BG74 & {$[\mathrm{m}]$} & 62.38 & 19.62 & 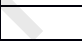 & 28.82 & 2.5 & 12 & 21 & 0.32 & & 0.46 & & 1.47 & \\
\hline POM 219.8 & {$[\mathrm{M}]$} & 52.90 & 17.52 & + & 22.60 & 1.60 & 10 & 33 & 0.33 & & 0.43 & & 1.29 & \\
\hline POM 219.5 & {$[\mathrm{~m}]$} & 41.22 & 13.90 & & 17.12 & 1.62 & & & 0.34 & & 0.42 & & 1.23 & \\
\hline POM 219.2 - Fig. 12a-b & {$[\mathrm{m}]$} & 86.00 & 26.00 & & 44.00 & 2.60 & & & 0.30 & & 0.51 & & 1.69 & \\
\hline POM 219.12 & {$[\mathrm{M}]$} & 58.70 & 18.00 & & 28.54 & 1.70 & 7 & 32 & 0.31 & & 0.49 & & 1.59 & \\
\hline FSL $487736 \mathrm{c}$ & $?$ & 27.36 & 10.92 & 5.30 & 10.10 & & 6 & 36 & 0.40 & 0.19 & 0.37 & 0.49 & 0.92 & \\
\hline FSL $487736 \mathrm{f}$ & $?$ & 29.40 & 11.30 & & 12.40 & & 11 & & 0.38 & & 0.42 & & 1.10 & \\
\hline FSL $487736 \mathrm{~g}$ & {$[\mathrm{~m}]$} & 63.48 & 20.54 & 12.20 & 27.14 & 2.70 & 8 & 29 & 0.32 & 0.19 & 0.43 & 0.59 & 1.32 & \\
\hline FSL $487736 \mathrm{~h}$ & {$[\mathrm{~m}]$} & 40.10 & 12.30 & & 17.86 & 3.00 & & & 0.31 & & 0.45 & & 1.45 & \\
\hline FSL $487736 \mathrm{i}$ & {$[\mathrm{M}]$} & 57.90 & 18.78 & & & 1.54 & & & 0.32 & & 0.00 & & 0.00 & \\
\hline FSL 487733 a - Fig. 12c & {$[\mathrm{m}]$} & 54.08 & 16.88 & & 25.06 & 2.42 & & & 0.31 & & 0.46 & & 1.48 & \\
\hline FSL $487733 \mathrm{~b}$ & {$[\mathrm{~m}]$} & 46.30 & 15.20 & & 22.34 & 2.20 & & & 0.33 & & 0.48 & & 1.47 & \\
\hline FSL 487733 e - Fig. 12e & {$[\mathrm{m}]$} & 40.16 & 13.30 & & & & 9 & 46 & 0.33 & & 0.00 & & 0.00 & \\
\hline FSL $487733 \mathrm{f}$ - Fig. 12f & {$[\mathrm{m}]$} & 32.20 & 11.40 & & & & 11 & 30 & 0.35 & & 0.00 & & 0.00 & \\
\hline FSL 487733 j - Fig. $12 \mathrm{~g}$ & $?$ & 20.18 & 7.48 & & 8.62 & & 6 & 30 & 0.37 & & 0.43 & & 1.15 & \\
\hline FSL 4877331 & $?$ & 37.10 & 13.50 & & 14.30 & & & & 0.36 & & 0.39 & & 1.06 & \\
\hline FSL 487738 & {$[\mathrm{~m}]$} & 48.80 & 17.00 & & 20.80 & & & & 0.35 & & 0.43 & & 1.22 & \\
\hline FSL 487743 a - Fig. 12d & {$[\mathrm{m}]$} & 55.66 & 19.04 & 8.10 & 26.86 & 2.80 & 11 & 36 & 0.34 & 0.15 & 0.48 & 0.43 & 1.41 & \\
\hline
\end{tabular}




\begin{tabular}{|l|l|l|l|l|l|l|l|}
\hline $\begin{array}{l}\text { Normality } \\
\text { tests }\end{array}$ & $\mathrm{D}$ & $\mathrm{h}$ & $\mathrm{Nt} / 2$ & $\mathrm{Ni} / 2$ & $\mathrm{H} / \mathrm{D}$ & $\mathrm{U} / \mathrm{D}$ & $\mathrm{U} / \mathrm{H}$ \\
\hline $\mathrm{N}$ & 36 & 29 & 20 & 20 & 36 & 35 & 35 \\
\hline $\begin{array}{l}\text { Shapiro-Wilk } \\
\mathrm{W}\end{array}$ & 0.9861 & 0.8557 & 0.8731 & 0.938 & 0.983 & 0.9715 & 0.9898 \\
\hline p(normal) & 0.9228 & 0.0009995 & 0.01335 & 0.2194 & 0.8415 & 0.4855 & 0.9828 \\
\hline
\end{tabular}




\begin{tabular}{|l|l|l|}
\hline PC & Eigenvalue & \% variance \\
\hline 1 & 4.05054 & 57.865 \\
\hline 2 & 1.00108 & 14.301 \\
\hline 3 & 0.948792 & 13.554 \\
\hline 4 & 0.571191 & 8.1599 \\
\hline 5 & 0.266392 & 3.8056 \\
\hline 6 & 0.159531 & 2.279 \\
\hline 7 & 0.00247875 & 0.035411 \\
\hline
\end{tabular}




\begin{tabular}{|l|l|l|l|l|l|l|l|}
\hline & PC 1 & PC 2 & PC 3 & PC 4 & PC 5 & PC 6 & PC 7 \\
\hline $\mathrm{D}$ & 0.42444 & 0.0075554 & 0.15133 & -0.35641 & 0.80451 & 0.14899 & 0.020707 \\
\hline $\mathrm{h}$ & 0.35504 & -0.072193 & 0.11709 & 0.89564 & 0.20663 & -0.10065 & 0.0051982 \\
\hline $\mathrm{Nt} / 2$ & -0.13147 & 0.62224 & 0.75266 & -0.0030951 & -0.049202 & -0.16308 & -0.0012766 \\
\hline $\mathrm{Ni} / 2$ & -0.10706 & -0.76078 & 0.62253 & -0.067397 & -0.099499 & 0.08799 & -0.0049681 \\
\hline $\mathrm{H} / \mathrm{D}$ & -0.4626 & 0.1036 & 0.0042742 & 0.22423 & 0.19762 & 0.72089 & 0.40773 \\
\hline $\mathrm{U} / \mathrm{D}$ & 0.46358 & 0.13295 & 0.084777 & -0.021826 & -0.37895 & 0.64311 & -0.45008 \\
\hline $\mathrm{U} / \mathrm{H}$ & 0.16806 & 0.22109 & -0.1251 & 0.71473 & 0.017449 & 0.017449 & 0.56262 \\
\hline
\end{tabular}




\begin{tabular}{|l|l|l|l|l|l|l|}
\hline & $\mathrm{h}$ & $\mathrm{Nt} / 2$ & $\mathrm{Ni} / 2$ & $\mathrm{H} / \mathrm{D}$ & $\mathrm{U} / \mathrm{D}$ & $\mathrm{U} / \mathrm{H}$ \\
\hline $\mathrm{D}$ & $\mathrm{rs}=0.61082$ & $\mathrm{rs}=-0.18903$ & $\mathrm{rs}=-0.14793$ & $\mathrm{rs}=-0.73707$ & $\mathrm{rs}=0.75062$ & $\mathrm{rs}=0.77383$ \\
& $p=0.00043261$ & $p=0.42476$ & $p=0.53369$ & $p=2.9521 \mathrm{E}-07$ & $p=2.0688 \mathrm{E}-07$ & $p=4.9882 \mathrm{E}-08$ \\
\hline $\mathrm{h}$ & & $\mathrm{rs}=-0.20082$ & $\mathrm{rs}=-0.18942$ & $\mathrm{rs}=-0.60044$ & $\mathrm{rs}=0.6745$ & $\mathrm{rs}=0.68515$ \\
& & $p=0.4558$ & $p=0.46652$ & $p=0.0005739$ & $p=8.2778 \mathrm{E}-05$ & $p=5.7536 \mathrm{E}-05$ \\
\hline $\mathrm{Nt} / 2$ & & $\mathrm{rs}=0.0099851$ & $\mathrm{rs}=0.31352$ & $\mathrm{rs}=-0.24228$ & $\mathrm{rs}=-0.27324$ \\
& & & $p=0.96764$ & $p=0.17829$ & $p=0.30339$ & $p=0.24377$ \\
\hline $\mathrm{Ni} / 2$ & & & $\mathrm{rs}=0.11195$ & $\mathrm{rs}=-0.21551$ & $\mathrm{rs}=-0.19781$ \\
& & & $p=0.63841$ & $p=0.3615$ & $p=0.40316$ \\
\hline $\mathrm{H} / \mathrm{D}$ & & & & $\mathrm{rs}=-0.79611$ & $\mathrm{rs}=-0.94336$ \\
& & & & $p=1.0787 \mathrm{E}-08$ & $p=2.2428 \mathrm{E}-17$ \\
\hline $\mathrm{U} / \mathrm{D}$ & & & & & $\mathrm{rs}=0.94638$ \\
& & & & & & \\
& & & & & & \\
\hline
\end{tabular}


ANOSIM

Permutation N:

Mean rank within:

Mean rank between:

R:

$p$ (same):
100,000

294.4

329.9

0.1126

0.07049 


\begin{tabular}{|l|l|l|l|}
\hline Dimorphs & Macro & micro & indet \\
\hline Macroconchs & & 0.00529 & 1 \\
\hline microconchs & 0.00529 & & 0.4511 \\
\hline indeterminate antidimorphs & 1 & 0.4511 & \\
\hline
\end{tabular}




\begin{tabular}{|c|c|c|c|c|c|c|}
\hline \multicolumn{4}{|c|}{ Standard zonation (from Reboulet et al., 2018) } & \multicolumn{3}{|c|}{ Zonation proposed in the present work (in grey: not studied) } \\
\hline Stage & Zone & Subzone & $\begin{array}{l}\text { Interval } \\
\text { Horizon }\end{array}$ & Zone & Subzone & Interval Horizon \\
\hline \multirow{6}{*}{ 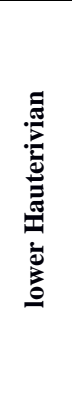 } & $\begin{array}{c}\text { Lyticoceras } \\
\text { nodosoplicatum }\end{array}$ & & O. variegatus & $\begin{array}{c}\text { Lyticoceras } \\
\text { nodosoplicatum }\end{array}$ & & O. variegatus \\
\hline & \multirow{3}{*}{$\begin{array}{c}\text { Crioceratites } \\
\quad \text { loryi }\end{array}$} & $\begin{array}{c}\text { Olcostephanus } \\
\text { jeannoti }\end{array}$ & & \multirow{3}{*}{$\begin{array}{l}\text { Crioceratites } \\
\text { claveli (new) }\end{array}$} & $\begin{array}{c}\text { Olcostephanus } \\
\text { jeannoti }\end{array}$ & \\
\hline & & \multirow{2}{*}{$\begin{array}{c}\text { Crioceratites } \\
\text { loryi }\end{array}$} & & & \multirow{2}{*}{ C. claveli (new) } & $\begin{array}{c}\text { C. loryi } \\
\text { C. claveli upper }\end{array}$ \\
\hline & & & & & & C. claveli lower \\
\hline & \multirow{2}{*}{$\begin{array}{c}\text { Acanthodiscus } \\
\text { radiatus }\end{array}$} & & & \multirow{2}{*}{$\begin{array}{l}\text { Acanthodiscus } \\
\text { radiatus }\end{array}$} & & \\
\hline & & & $\begin{array}{c}\text { Breistrofferella } \\
\text { castellanensis }\end{array}$ & & & $\begin{array}{c}\text { Breistrofferella } \\
\text { castellanensis }\end{array}$ \\
\hline
\end{tabular}




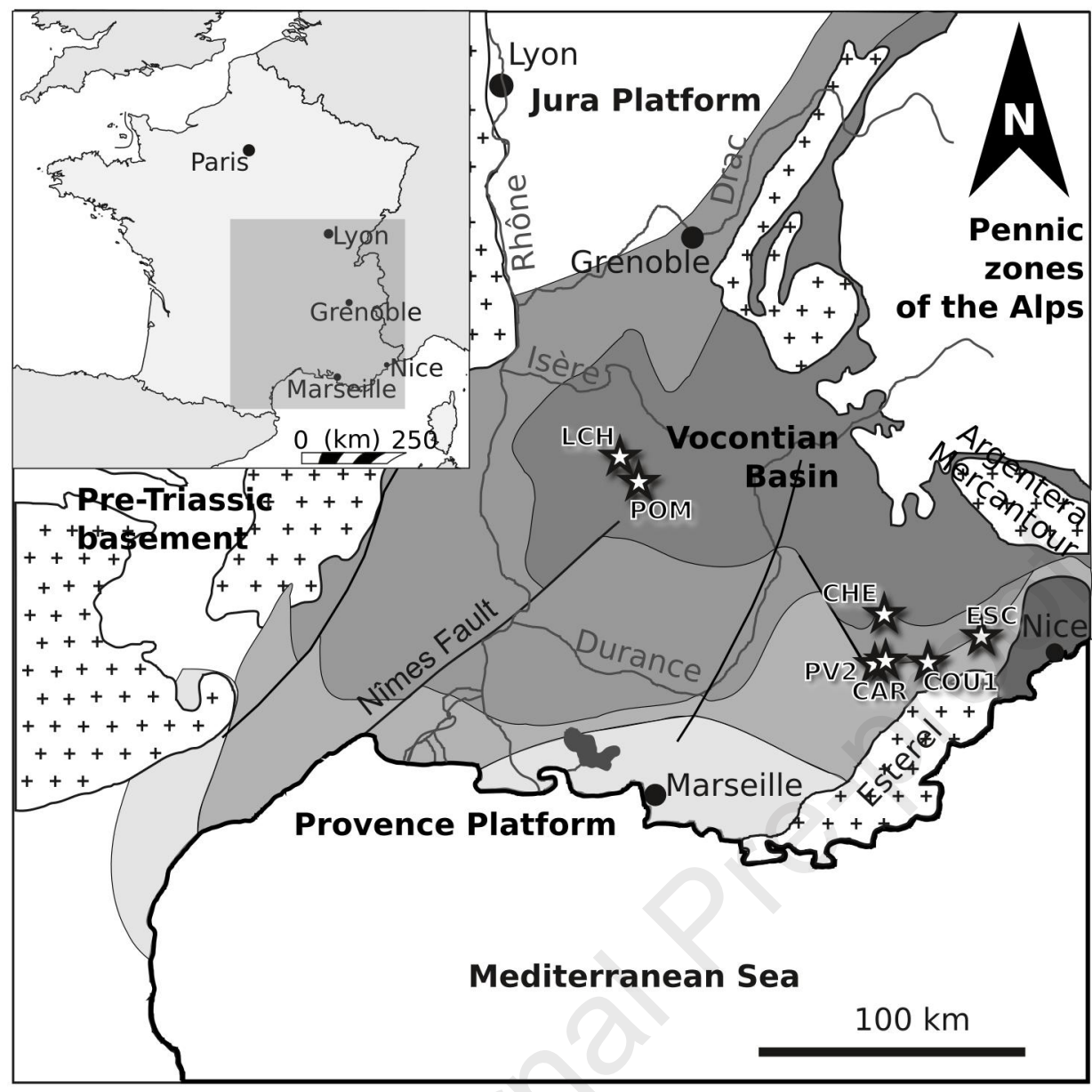

Deep open marine environment (pelagic)

Shallow open marine environment (hemipelagic)

Drowned platform

(marly limestones)

Drowned platform (bioclastic facies)

Drowned platform (condensed series) 


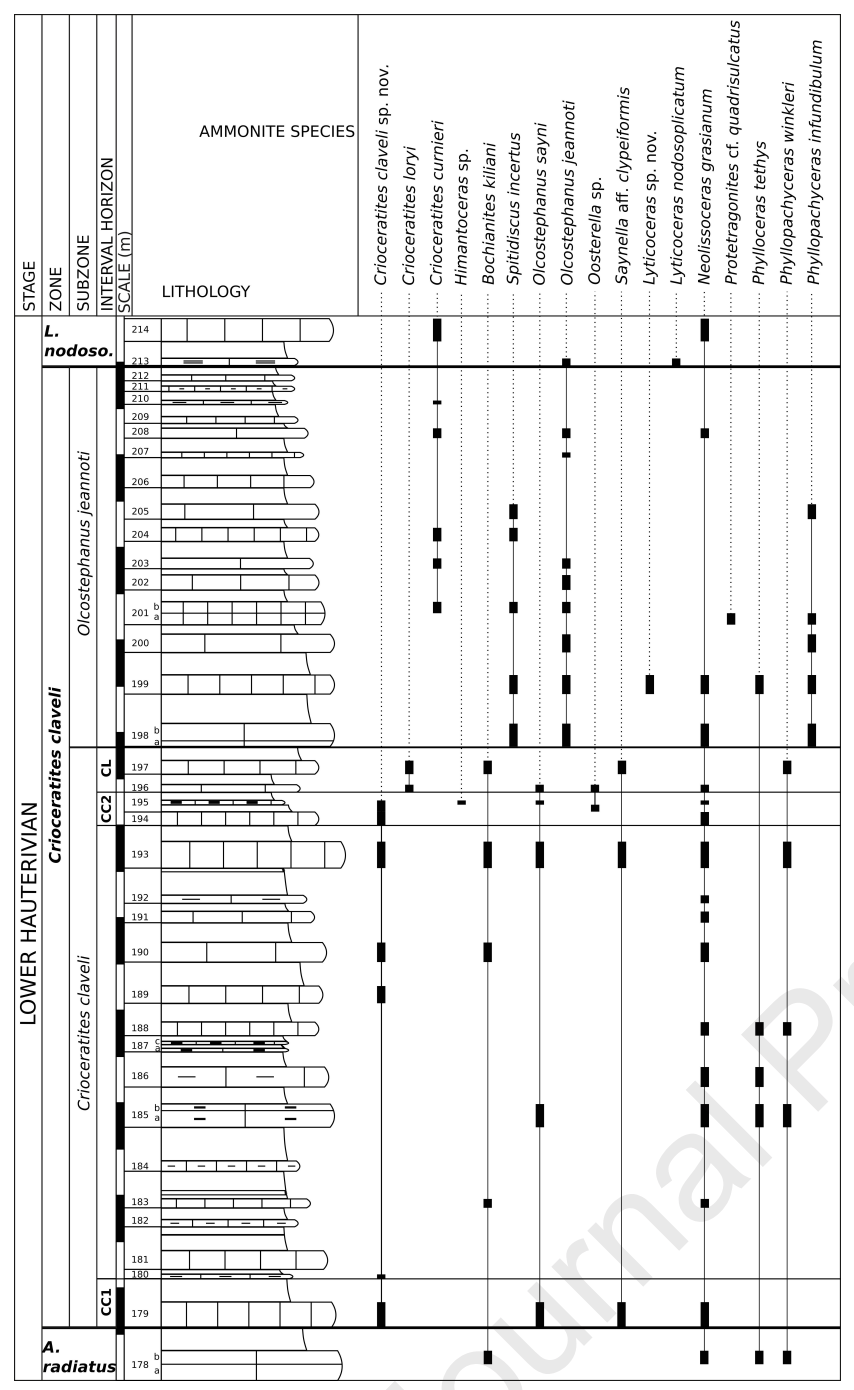




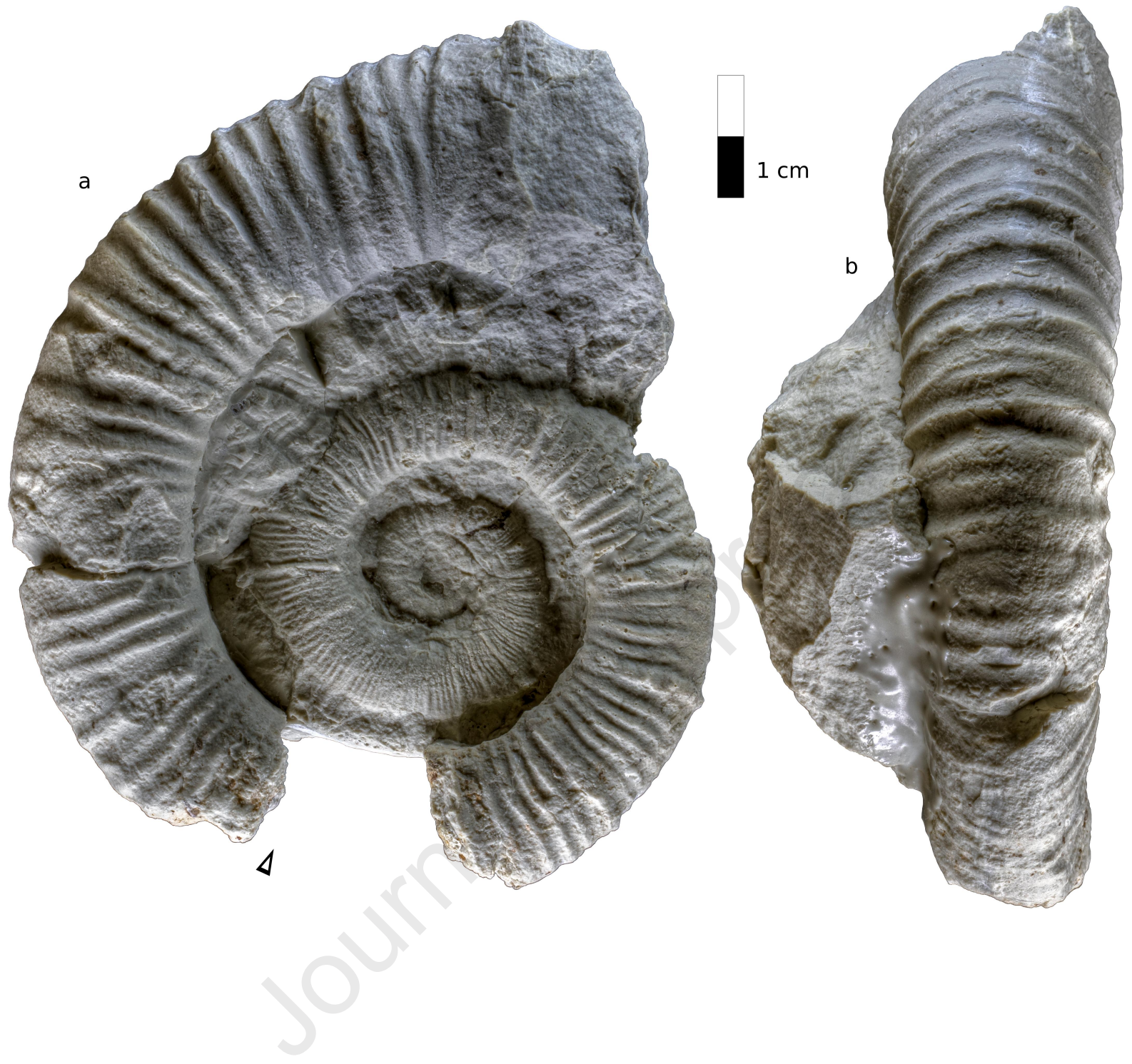



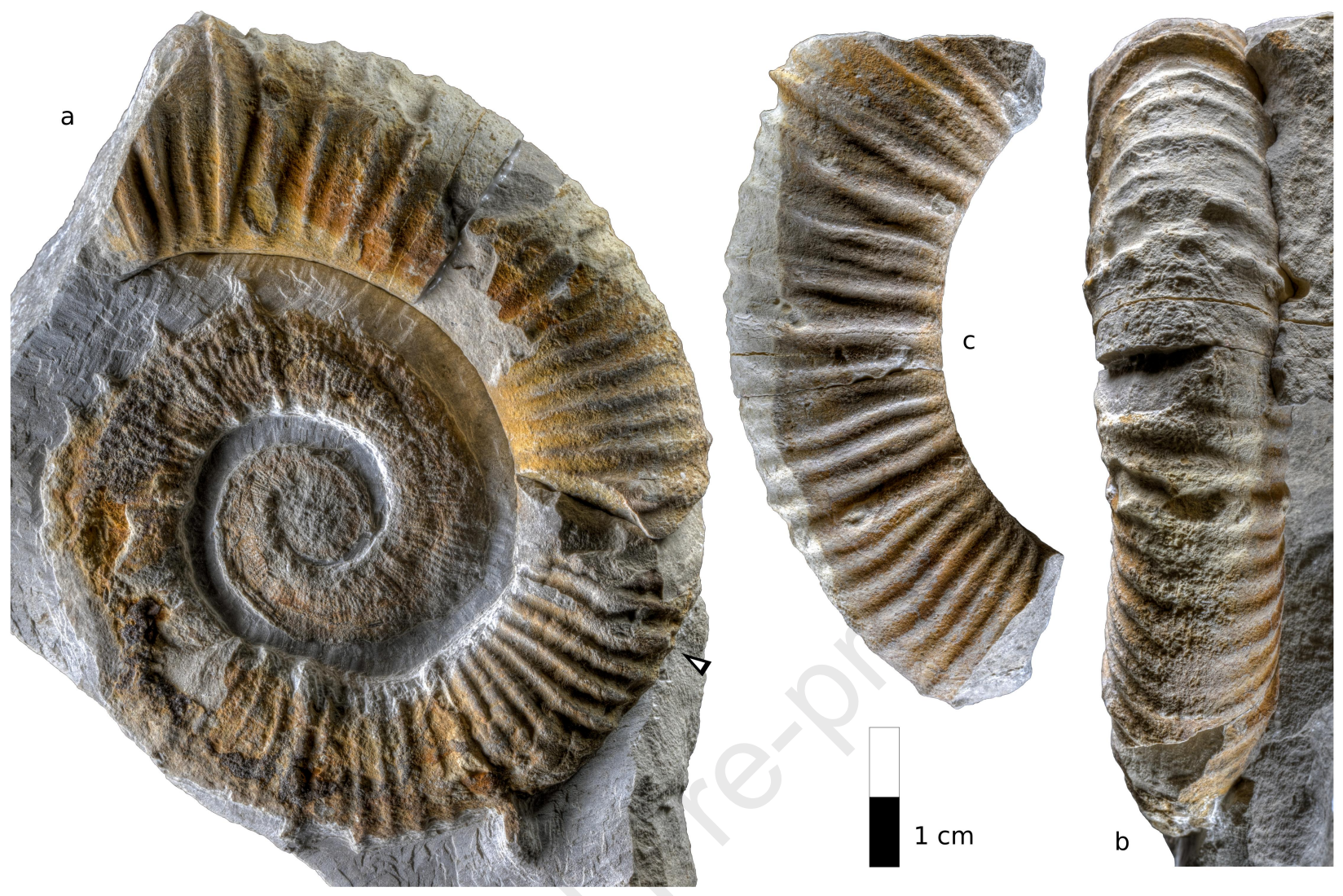


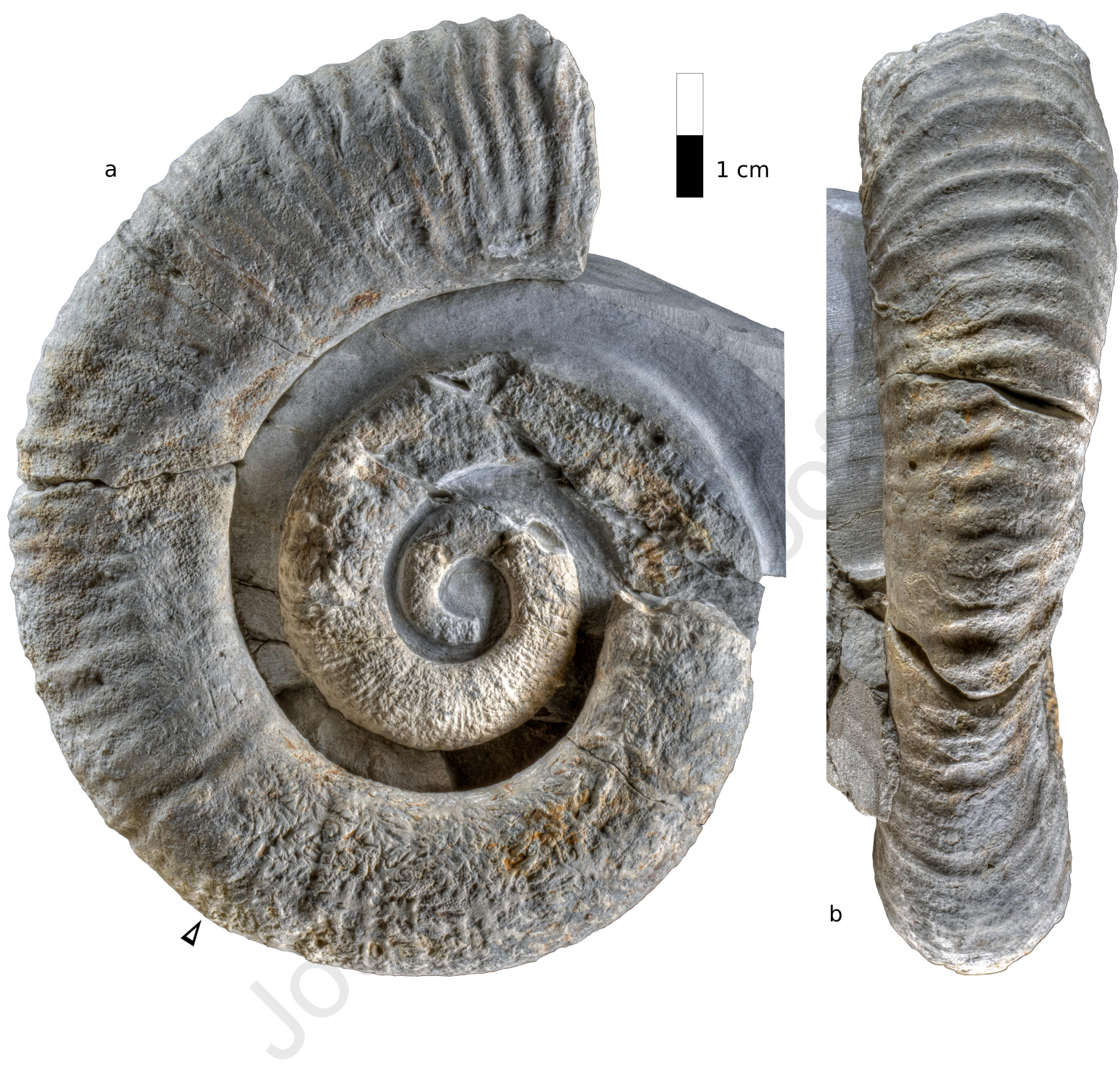




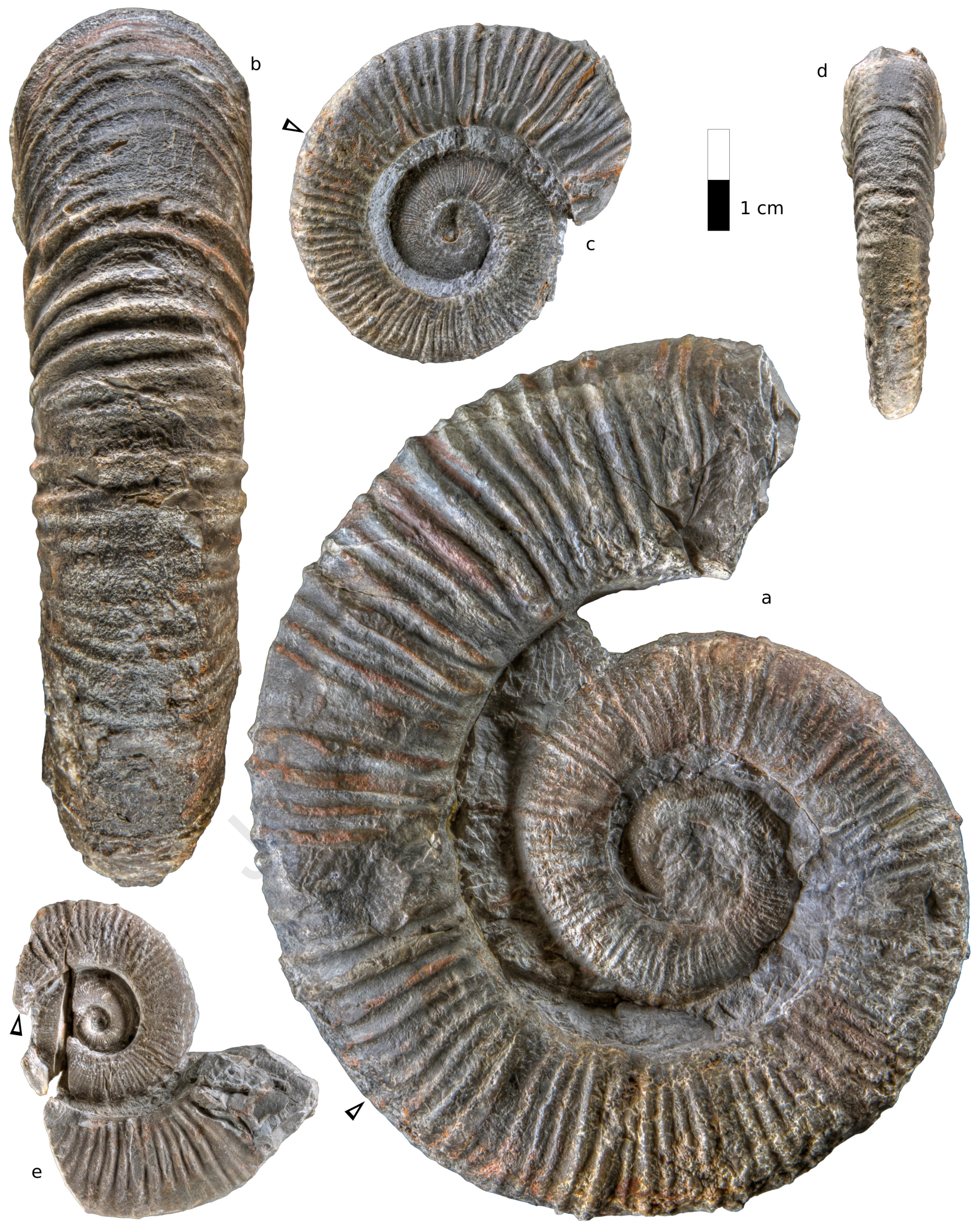



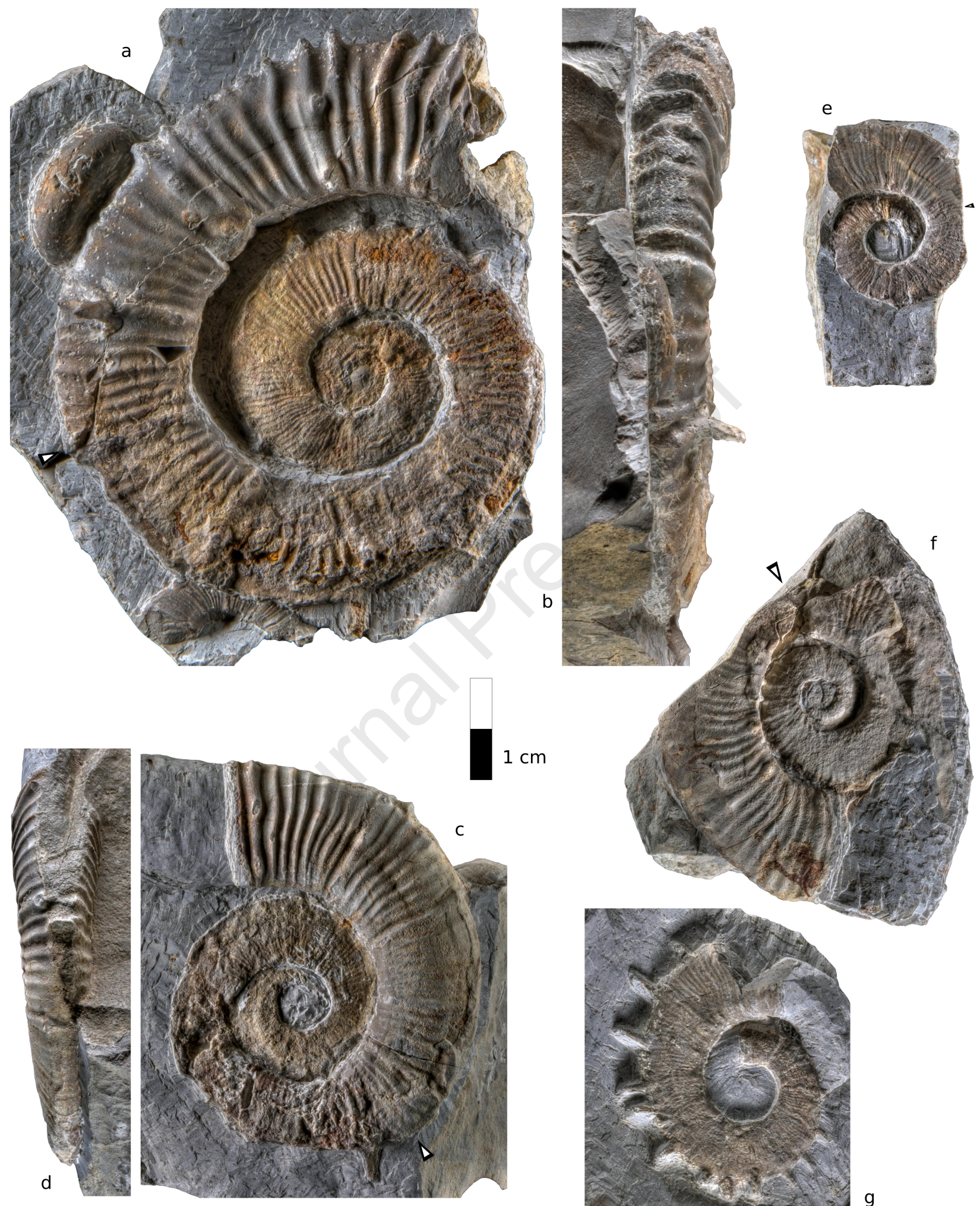

$1 \mathrm{~cm}$

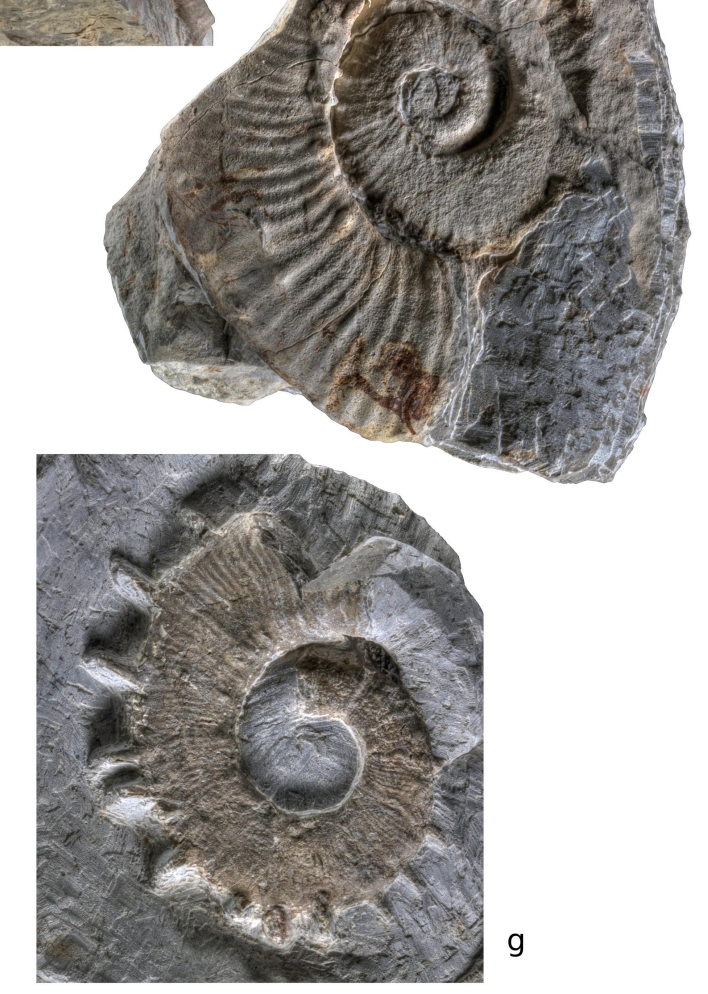




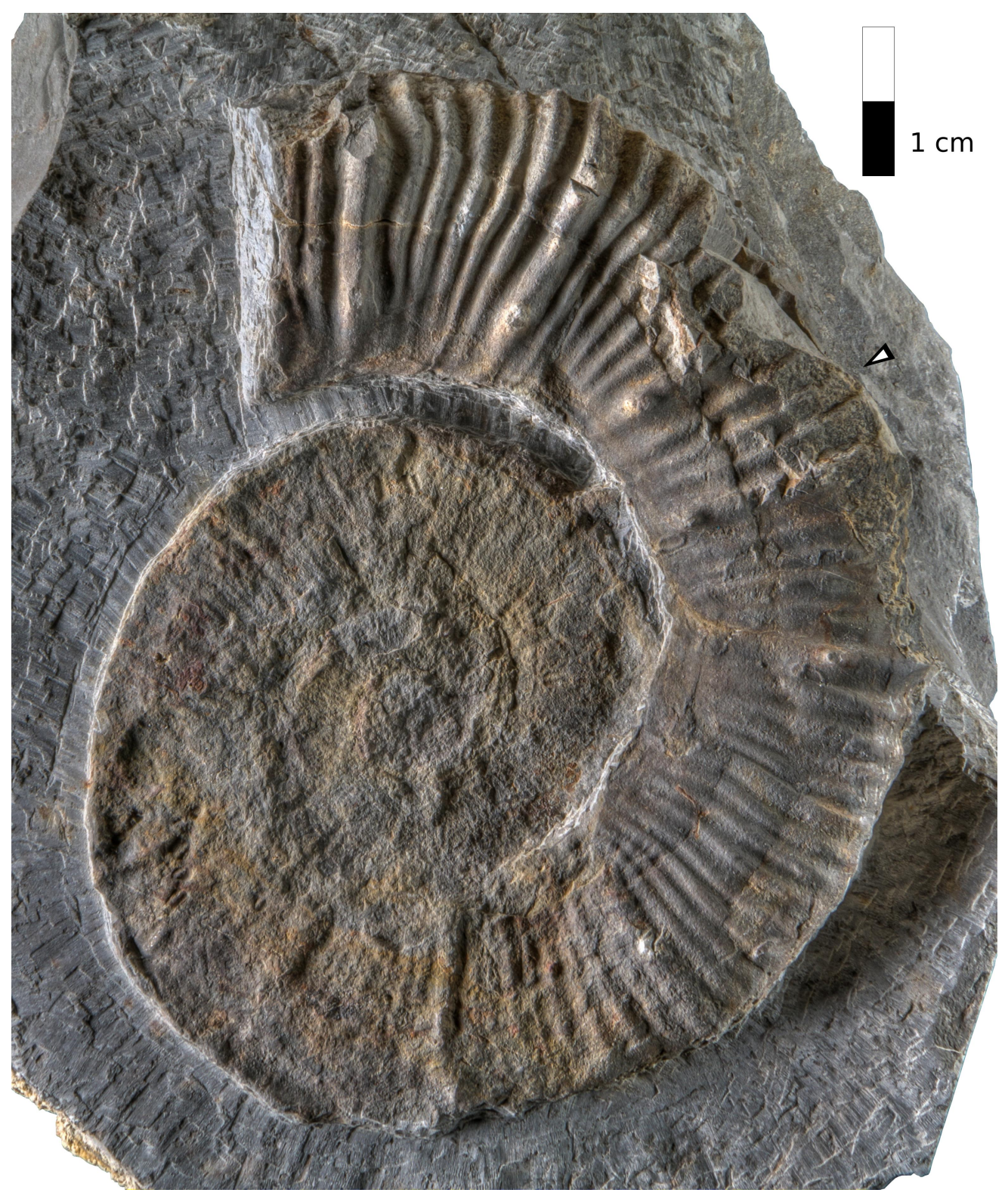




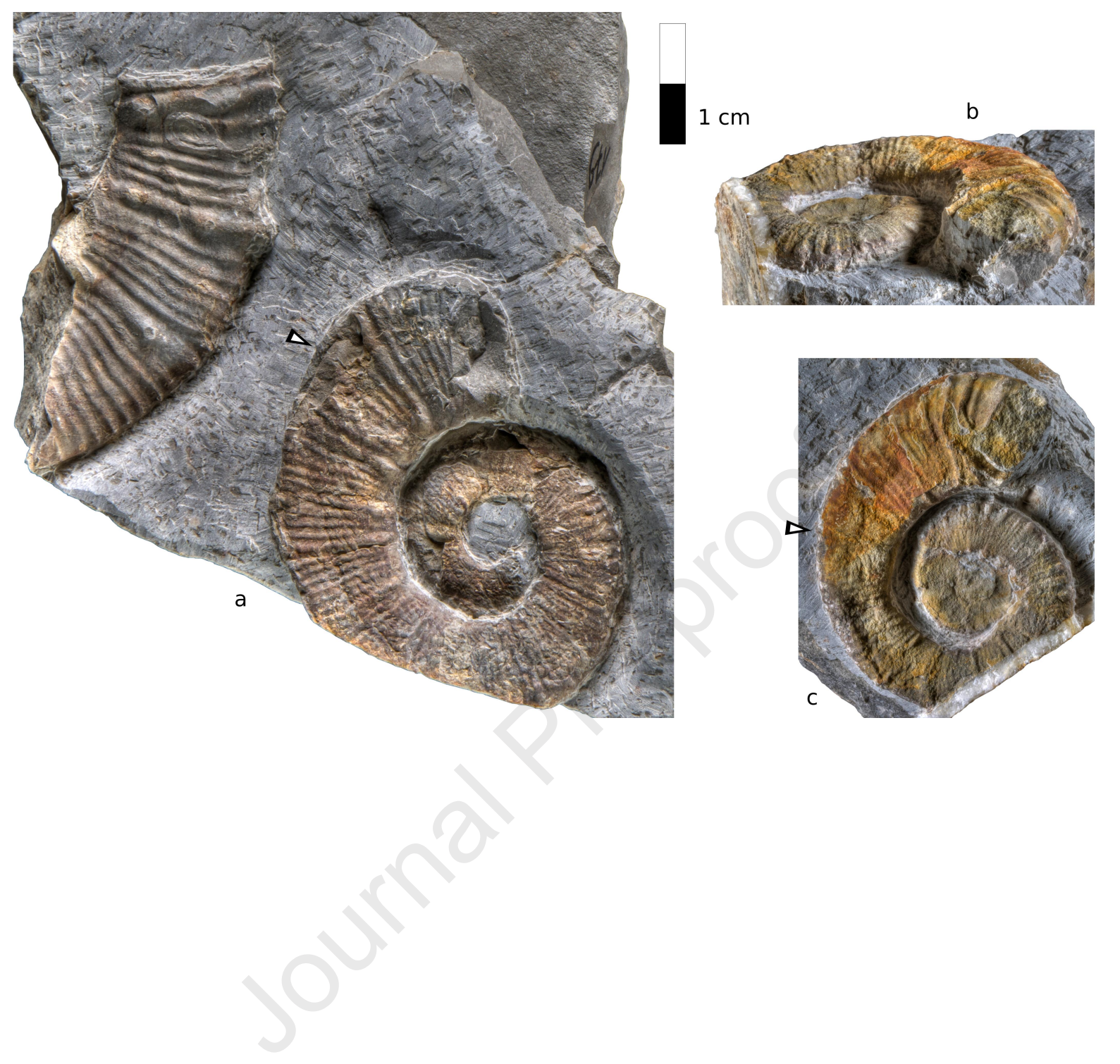




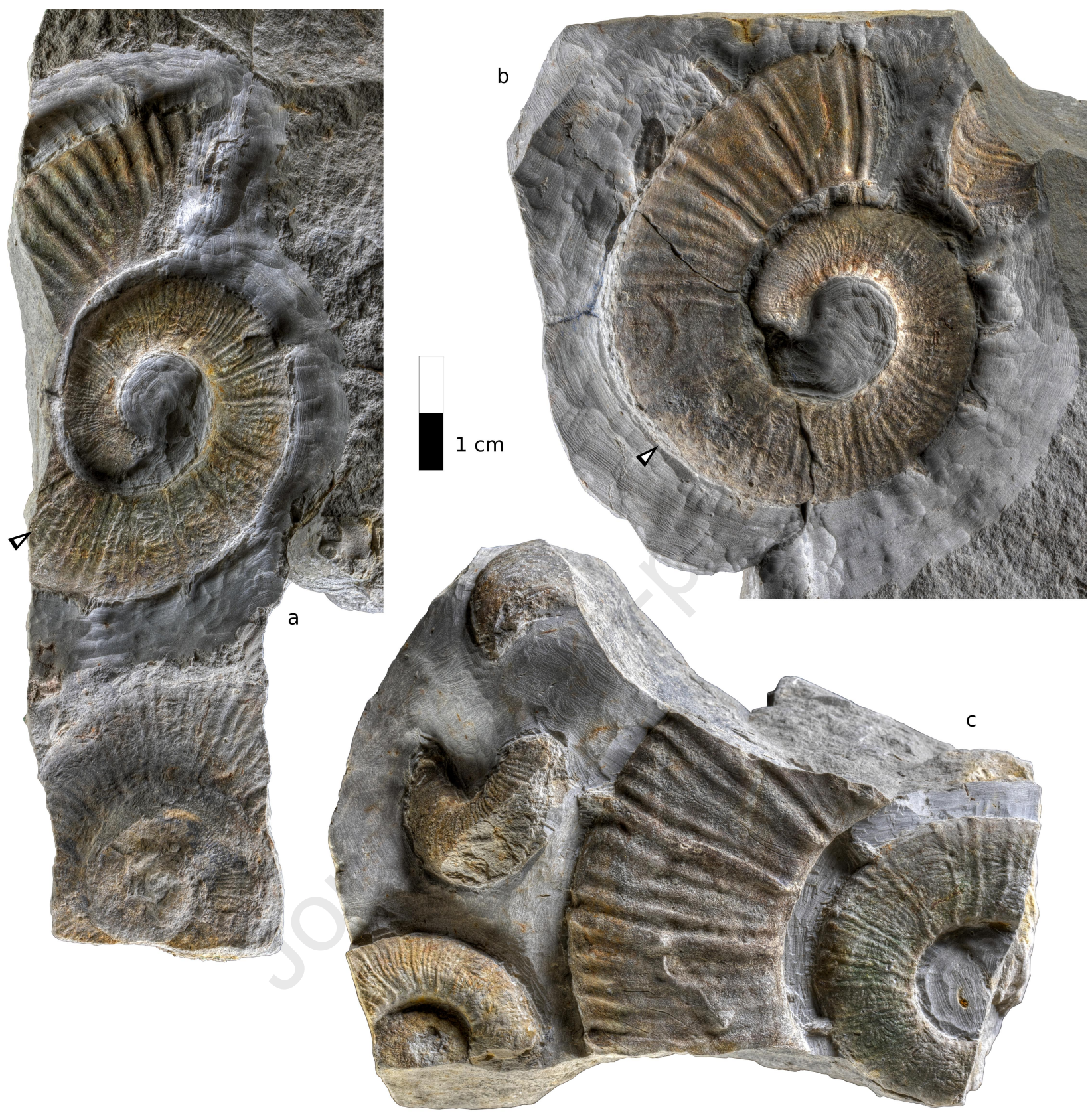




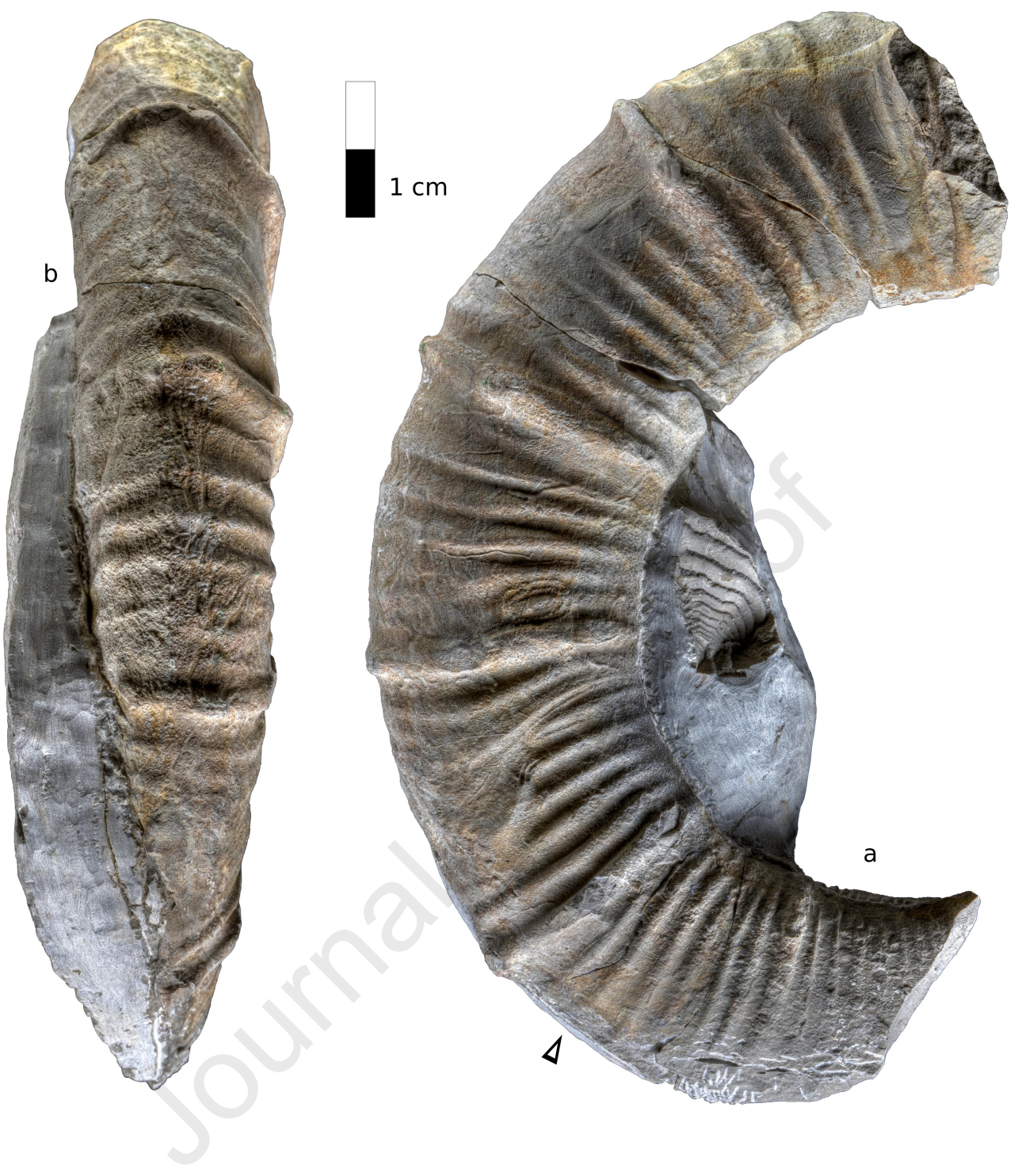



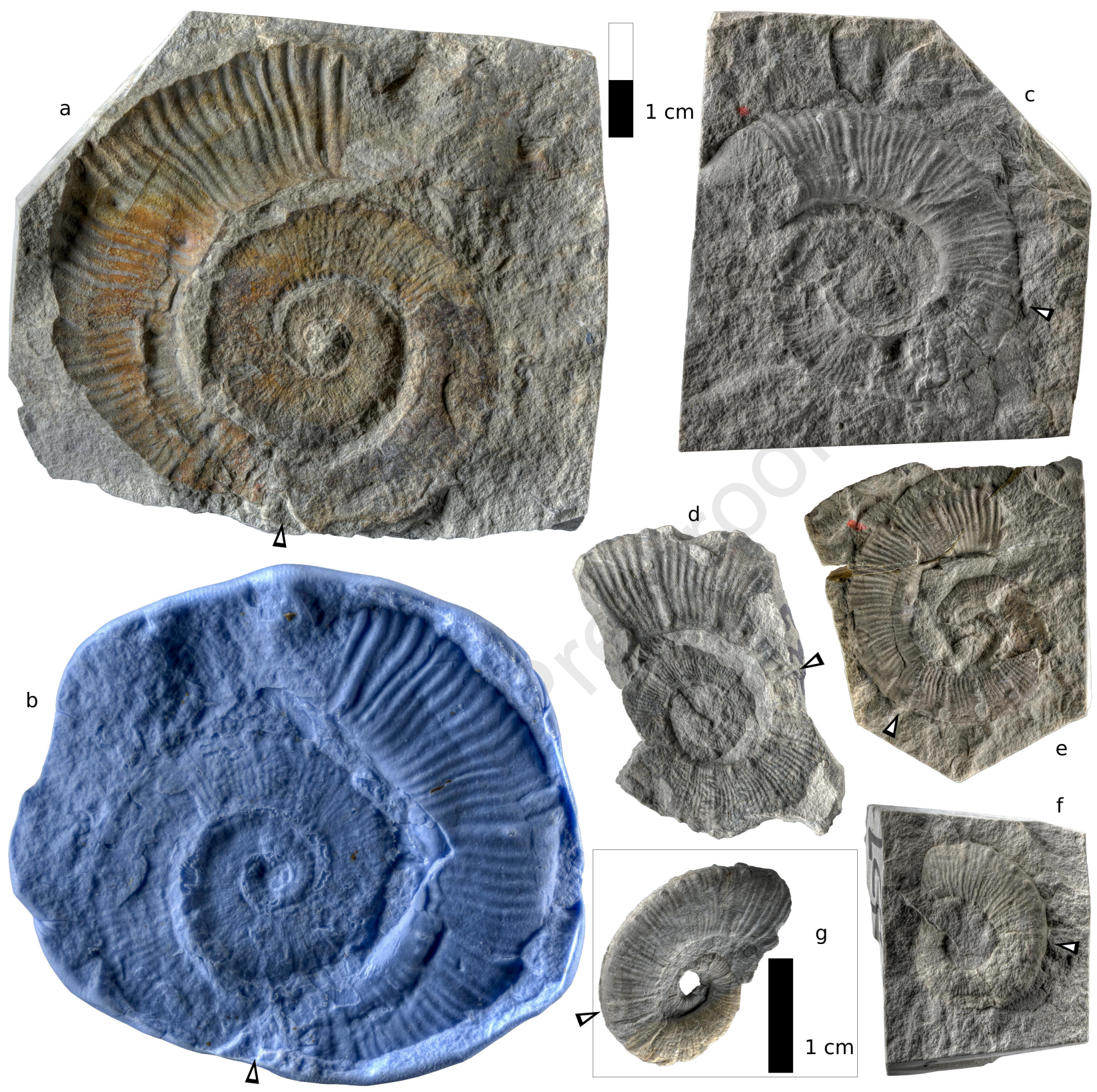

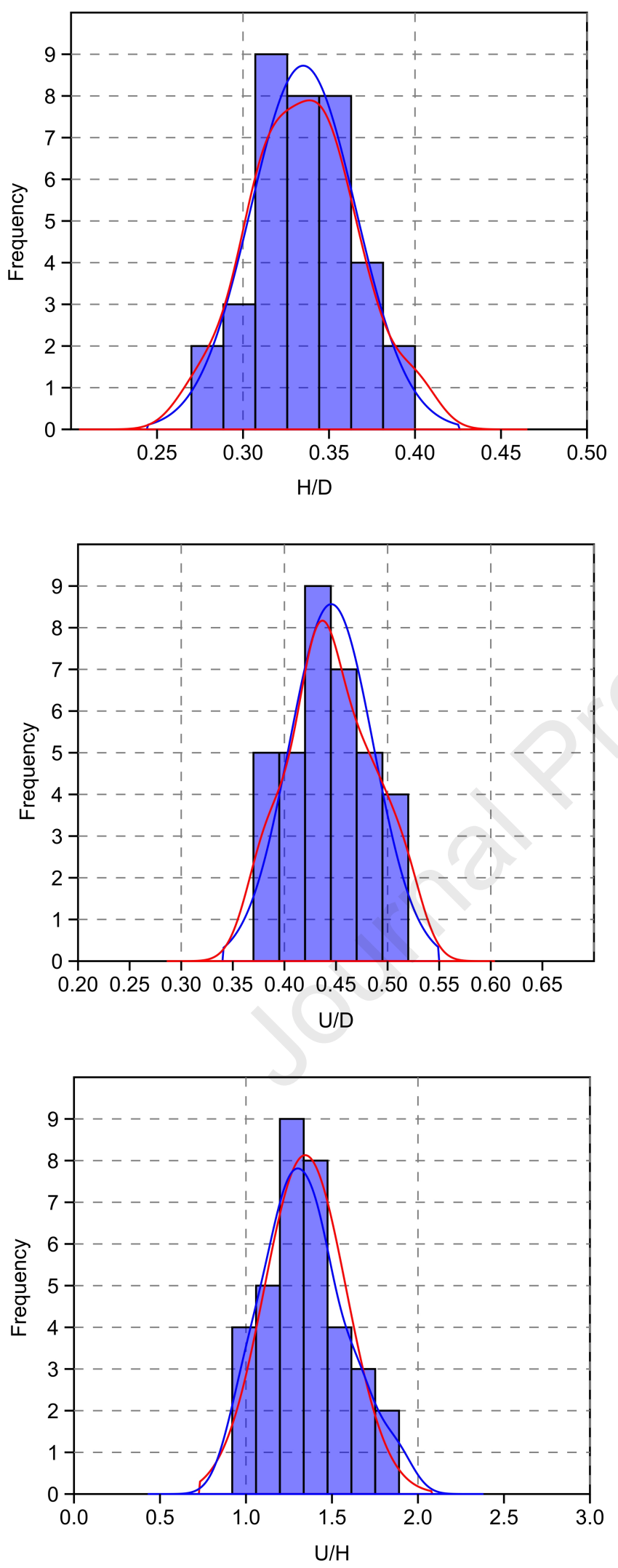

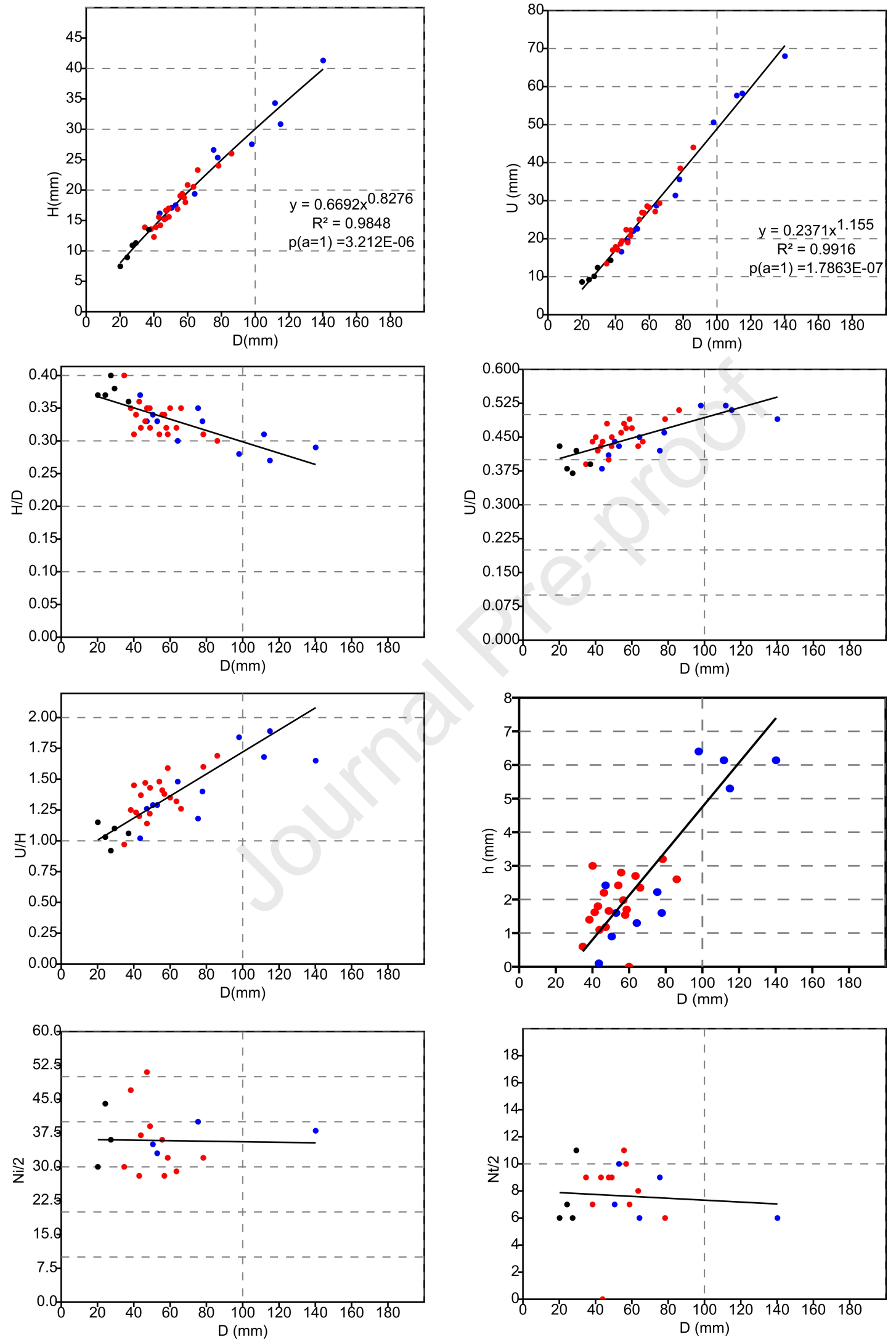

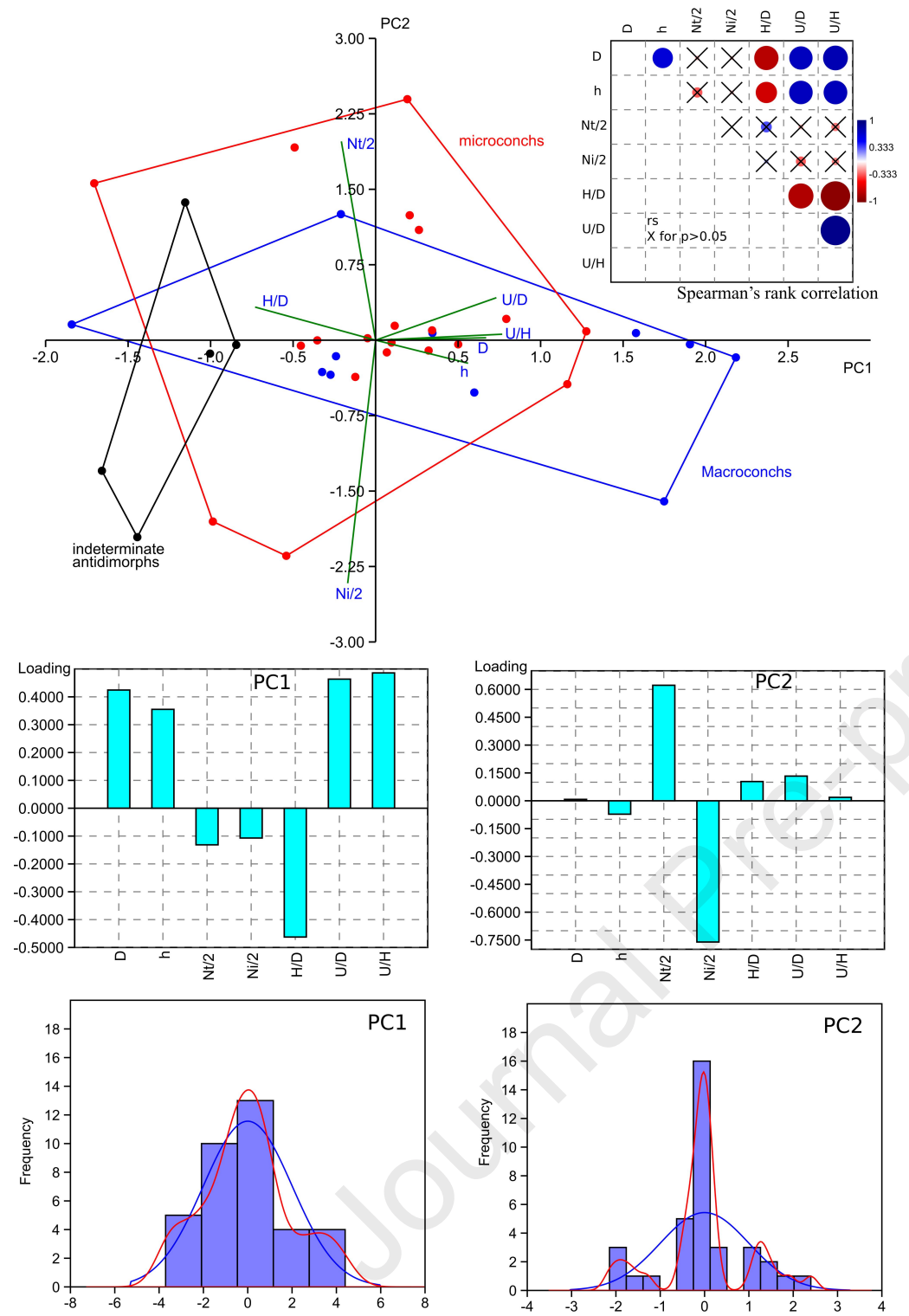


\section{Declaration of interests}

$X$ The authors declare that they have no known competing financial interests or personal relationships that could have appeared to influence the work reported in this paper.

$\square$ The authors declare the following financial interests/personal relationships which may be considered as potential competing interests:

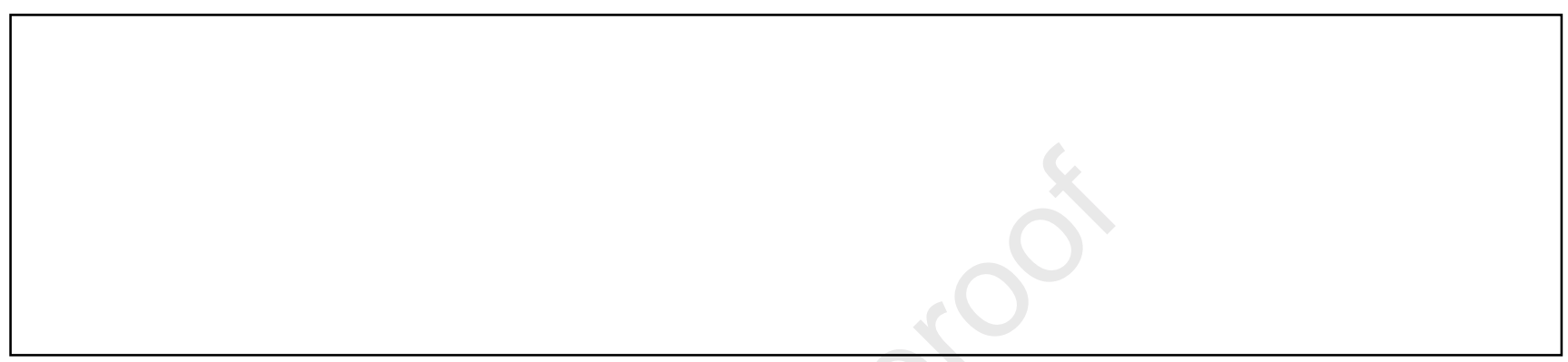

